
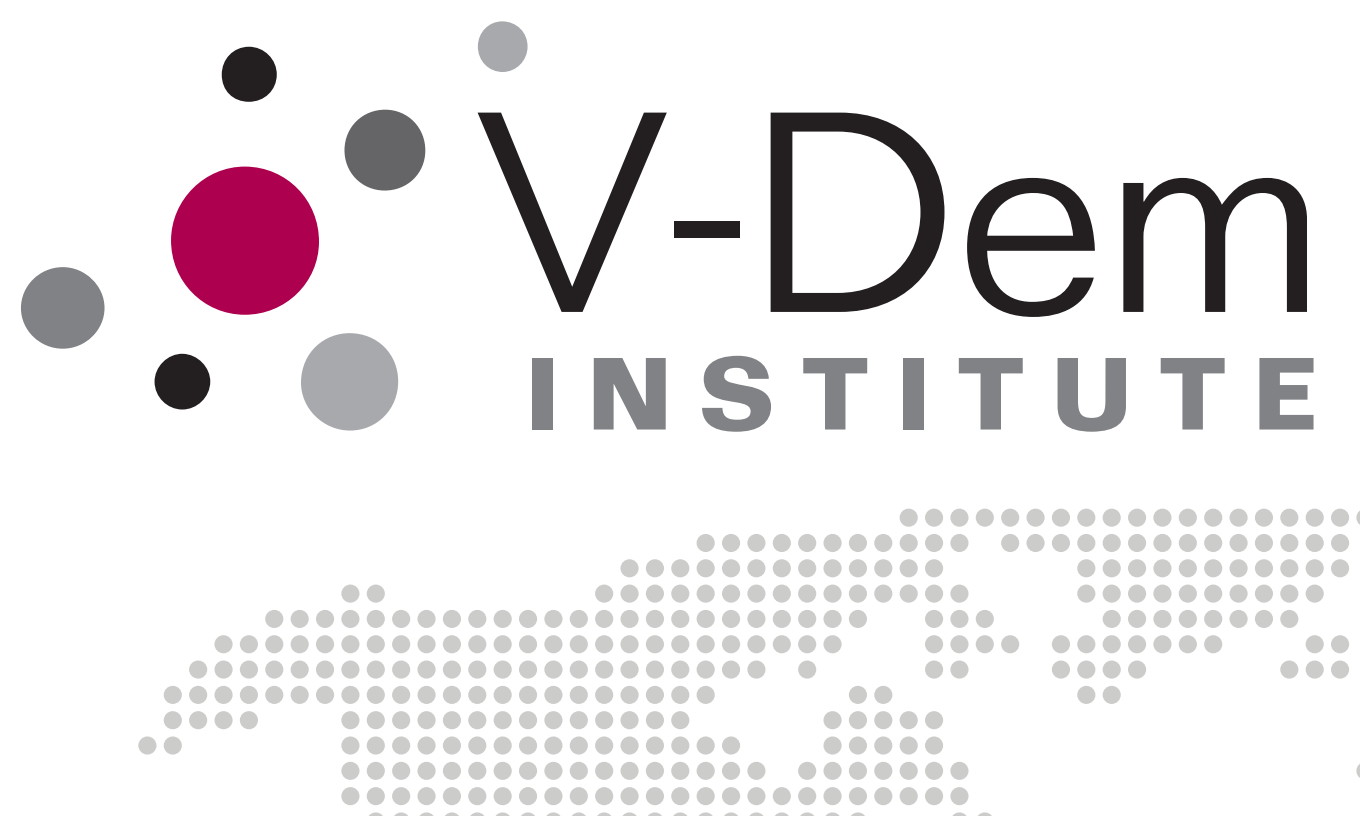
1000
100

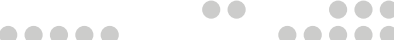

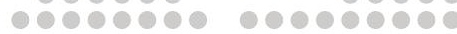
$0000000900009000 \mathrm{c}$ $0000000000000000 \mathrm{c}$

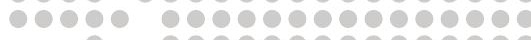
$000000000000000000 \mathrm{C}$ -

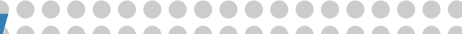

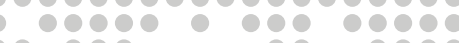
OP 100

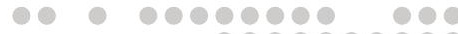

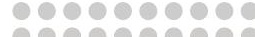

1000

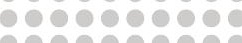
and Governance

Maria C. Lo Bue, Kunal Sen, Staffan I. Lindberg
00000000

0000000

100000

10000

10000

000

000

10

100

80 0000000000000

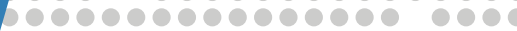

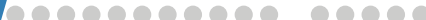

$80^{30}$

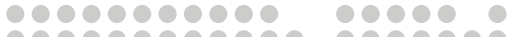

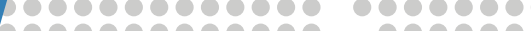

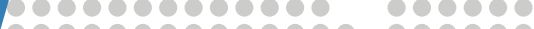

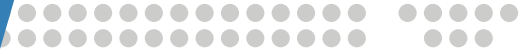
3000000000000000 00000000000000000000

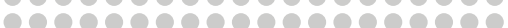
90000000000000

b900090000909

10000000000

00000000000 1000000000

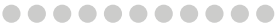

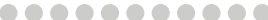

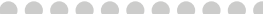
-

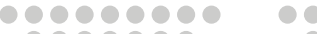
0000000 000000 1000 ○ी 
Varieties of Democracy (V-Dem) is a new approach to conceptualization and measurement of democracy. The headquarters - the V-Dem Institute - is based at the University of Gothenburg with 23 staff. The project includes a worldwide team with 5 Principal Investigators, 19 Project Managers, 33 Regional Managers, 134 Country Coordinators, Research Assistants, and 3,500 Country Experts. The V-Dem project is one of the largest ever social science research-oriented data collection programs.

Please address comments and/or queries for information to:

\author{
V-Dem Institute \\ Department of Political Science \\ University of Gothenburg \\ Sprängkullsgatan 19, Box 711 \\ 40530 Gothenburg \\ Sweden \\ E-mail: contact@,v-dem.net
}

V-Dem Working Papers are available in electronic format at www.v-dem.net.

Copyright (C2021 by authors. All rights reserved. 


\title{
Clientelism, public goods provision, and governance*
}

\author{
Maria C. Lo Bue \\ UNU-WIDER \\ Kunal Sen \\ UNU-WIDER \\ Staffan I. Lindberg \\ V-Dem Institute
}

\footnotetext{
* The authors are grateful to Nina Ilchenko, Carl Henrik Knutsen, Miguel Niño-Zarazúa, and all the participants of the WIDER workshop on 'Clientelistic Politics and Development'. This study is reproduced here with full acknowledgement of UNU-WIDER, Helsinki. The study was originally commissioned under the UNU-WIDER project Clientelist politics and economic development - theories, perspectives and new directions. Copyright: (C) UNU-WIDER.
} 


\begin{abstract}
It is widely believed that clientelism — the giving of material goods in return for electoral support-is associated with poorer development outcomes. However, systematic crosscountry evidence on the deleterious effects of clientelism on development outcomes is lacking. In this paper we examine the relationship between political clientelism, public goods provision, and governance quality using cross-country panel data for 161 countries for the period 1900-2017. We distinguish between two manifestations of political clientelismwhether vote buying exists, and whether political parties offer material goods to their constituents in exchange for political support (non-programmatic party linkages). We find negative effects of political clientelism on development outcomes, with increases in clientelism leading to lower coverage of welfare programmes, increased political corruption, and weaker rule of law. We also find that the deleterious effects of political clientelism are mainly through non-programmatic party linkages rather than the practice of vote buying.
\end{abstract}




\section{Introduction}

The pervasiveness of political clientelism, which reflects strategic, discretionary, and targeted exchange of private goods and services for political support, has been documented in country case studies and political ethnography (e.g., Auyero 2000; Kitschelt and Wilkinson 2007; Lindberg 2003; Lust-Okar 2009; Scott 1969; Stokes 2005).

Political clientelism is typically argued to subvert democracy and development in a variety of ways: reducing supply of public goods, increasing corruption, and weakening the rule of law (Bardhan and Mookherjee 2020; Hicken 2011; Stokes et al. 2013). But systematic evidence on the effects of clientelism on development outcomes is lacking. In this paper, we examine the effects of political clientelism on public goods provision, corruption, and the rule of law for a large number of developing and developed countries for the period 19002017.

We examine two mechanisms by which political clientelism may affect development outcomes. First, political clientelism is expected to lead to the under-provision of public goods as political leaders choose inefficient forms of redistribution such as offers of employment in the bureaucracy to ensure that they have the support of a particular group of citizens (Nathan 2019; Powell 1970; Robinson and Verdier 2013). Second, political clientelism should be associated with higher levels of corruption and weaker enforcement of property rights, leading to lower governance quality, as politicians would be expected to seek access to illicit sources of funds to finance vote buying or selectively enforce property rights so as to favour their own supporters (Holland 2016; Keefer and Vlaicu 2008; Schmidt et al. 1977).

A key limitation in the previous empirical literature on clientelism has been the lack of comparable measures of the practice of political clientelism across a sufficiently large number of countries and long periods, which allows for a rigorous cross-country analysis of effects. In this paper, we utilize a recently released set of measures of political clientelism provided by V-Dem (Coppedge et al. 2019b) that are available for a large number of countries for the period 1900-2017. We look at two dimensions of political clientelism-party linkages and election vote buying. Party linkages refer to the sort of goods that political parties offer in exchange for political support. Election vote buying refers to the distribution of money or gifts to individuals, families, or small groups in order to influence their vote choice or turnout. Both party linkages and vote buying have been seen as important manifestations of the practice of political clientelism in most regions of the world (Hicken 2011; Johnston 1979). 
For example, after Argentina's return to democracy in 1983, the Peronist party engaged in pervasive vote buying as well as targeted material benefits to their supporters (Stokes 2005). In Singapore, the government invested heavily in improvements and maintenance of housing, and openly used the programme as a way to reward constituents who voted for the ruling party and to punish those who did not (Stokes et al. 2013). These are only two country examples, but such clientelist practices are commonly seen in most developing countries, as well as some developed countries.

A strength of our analysis is that we use panel data for 161 countries covering the years 1900-2017, which allows us to study all of the twentieth century for both (now) developed and developing countries. This is important as many developed countries—such as Italy, the United Kingdom, and the United States—had pervasive clientelist practices in politics during the first half of the twentieth century, which declined in the second half (see Kitschelt and Wilkinson 2007; Lizzeri and Persico 2004; Nathan 2019; Wolfinger 1972). In this paper, we ask whether past practices of political clientelism in developed countries and more contemporary practices of such clientelism in developing countries have led to adverse development outcomes, such as a less universal coverage of welfare programmes, corruption, and weaker rule of law.

We find that differences in governance quality, as proxied by corruption and rule of law, are to a significant extent explained by differences in political clientelism. Countries featuring more pervasive clientelistic practices in politics also tend to be significantly less inclusive in their welfare programmes' coverage than countries with less political clientelism. In addition, we find that the deleterious effects of political clientelism on governance quality and public goods provisions tend to be conveyed mainly through non-programmatic party linkages rather than the practice of vote buying.

The rest of the paper is organized in five sections. Section 2 provides the conceptual framework. Section 3 describes the data. In Section 4 we discuss the empirical strategy and present our results. Section 5 concludes.

\section{Conceptual Framework}

There is a substantial theoretical and empirical literature on the relationship between clientelism and corruption, public goods provision, and governance outcomes. We draw on that literature to propose two testable hypotheses.

First, we consider the relationship between political clientelism and public goods provision. Two generic features of clientelism make it more likely that societies with a higher 
degree of political clientelism will have lower levels of public goods provision. Clientelism in general is an asymmetric, diffuse, and typically recurrent relationship between patrons and clients (e.g., Kaufman 1974; Landé 1983; Lemarchand 1972; Powell 1970; Scott 1972). When occurring between political parties and voters, the party in question may offer inducements to individual voters (or groups of voters) to bolster the party's electoral prospects. Given finite resources, political clientelism is expected to be reflected in public welfare spending as targeted redistributions rather than programmatic redistribution (Dixit and Londregan 1996). An electoral strategy in which political parties efficiently deliver targeted goods to citizens who are more likely to return the favour with their vote would be more cost-effective than a universal provision of public goods where the marginal benefit in terms of votes mobilized may be less than the marginal cost of the expenditures (Stokes 2011). Clientelistic benefits are excludable by their very nature and are denied to some voters, thus their distribution creates an inherent bias in favour of private or 'club' benefits versus public goods (Bardhan and Mookherjee 2020).

A second feature of political clientelism is that it is a political exchange built on a reciprocal relationship (even if diffuse and returns can be delayed) between the politician and the voter (Hicken 2011). The politician offers material goods to their supporters on the understanding that these individuals will reciprocate by voting for and expressing support for the politician or party. Given the low ability of politicians to make credible pre-electoral commitments to voters, politicians engage in inefficient redistribution such as offers of employment in the bureaucracy and other discretionary rents to the individuals who promise to vote for the politicians (Keefer and Vlaicu 2008; Lindberg 2010; Robinson and Verdier 2013). Taken together, the contingent, reciprocal nature of exchanges under political clientelism induces a bias away from universal provision of goods and services towards more discretionary public spending and targeted illicit private goods.

We suggest three causal pathways by which we should expected the effects of political clientelism to affect governance quality. First, political clientelism in the form of vote buying is typically illegal, which per definition is lowering governance quality. Second, political clientelism can foster a culture of impunity, making it difficult to punish corrupt officials by undermining the ability of citizens to hold public officials accountable through elections (Singer 2009). Finally, the demand for resources to support clientelist exchanges in politics (such as vote buying) should be expected to increase the incentives of politicians to raise funds through illicit means (Hicken 2011) and divert from the time they have for informed policy-making (Lindberg 2010). 
Political clientelism may also have a negative effect on the rule of law through the practice of forbearance, defined as intentional and revocable government leniency towards violations of the law' (Holland 2016: 2). In clientelist societies, politicians may be more likely to lean on law-enforcement authorities to selectively 'adjust' the rules (and the implications for their violations) in favour of specific groups of voters or potential voters (Holland 2006; Lindberg 2010).

An important feature of forbearance is its revocability-politicians can extend and retract forbearance at will. This implies that forbearance is more likely to be observed in clientelist societies. The contingent nature of the clientelist exchange in politics raises credible commitment problems, which political leaders try to address by practising forbearance as a vote-getting tool (Holland 2017). Therefore, the practice of forbearance in clientelist societies tends to weaken the rule of law, leading to a deterioration in the quality of governance over time.

The above discussion allows us to derive two testable hypotheses on the developmental implications of clientelism - that is, that clientelism leads to an under-provision of public goods and that it leads to a weakening of the rule of law and higher levels of corruption.

\section{Data}

Our main analysis is based on a panel of 161 countries tracked from 1900 to 2017 drawn from the VDem data set (Coppedge et al. 2019b). This data set represents a valuable and unique tool to study the geopolitical distribution and the historical trends of political clientelism, corruption, and public goods provision.

\subsection{Clientelism-related variables}

As argued by Stokes et al. (2013), clientelism is a multifaceted concept. According to the earliest definitions provided in the literature (Gouldner 1960; Kaufman 1974; Landé 1977; Lemarchand 1972; Lemarchand and Legg 1972; Powell 1970; Scott 1972), clientelism can be broadly conceived as a 'dyadic alliance' between two groups of actors (the 'patrons' and the 'clients') featuring the following items: an unbalanced structure of power between them, repeated face-to face transactions, a diffuse exchange, and the utility that both parts gain in engaging in the alliance.

Other scholars (e.g. Robinson and Verdier 2013) have defined clientelism in terms of the exchange of a public sector job for political support, or in terms of an instrumental 
friendship' between the patron and the client, in which protection and security are given as a reward for personal loyalty and obedience (e.g. Scott 1972).

Here we embrace a specific definition of political clientelism. Following Stokes (2011), we define it as the informal and particularistic distribution of public funds from leaders to voters in exchange for political support (Stokes 2011). According to this definition, patronage and vote/turnout buying are two key expressions of political clientelism, which often manifest throughout the election cycle in the form of diffuse and repeated exchanges of money, jobs, or other benefits in exchange for political support.

The measure of political clientelism used in this analysis is an index $(v 2 \times n p-$ client $)$ constructed by taking the reversed point estimates (so that higher scores correspond to more clientelism) from a Bayesian factor analysis model of the indicators extracted from the VDem data set: 'vote buying' (v2elvotbuy-osp) and 'party linkages' (v2psprlnks-osp). ${ }^{1}$

Vote buying is measured as the prevalence of vote or turnout buying during each election year. The level of vote or turnout buying is an interval measure ranging from 0 (systemic vote or turnout buying) to 4 (no evidence of either occurring). ${ }^{2}$ Since this variable is only measured in the years in which elections takes place, we impute in the years in between elections the value of the variable as recorded in the last election year.

Political patronage is proxied by the party linkages indicator. Here the focus is on the type of 'goods' that parties offer in exchange for political support and participation in party activities. The indicator is an interval measure on a scale from 0 to 4 , mapping onto the original coding criteria for the experts' assessment of these party linkages. The original categories are: (0) 'clientelistic' (i.e. constituents are rewarded with goods, cash, and/or jobs); (1) 'mixed clientelistic and local collective'; (2) 'local collective' (e.g., wells, toilets, markets, roads, bridges, and local development); (3) 'mixed local collective and policy/programmatic';

\section{Figure 1: The evolution of clientelism around the world}

\footnotetext{
${ }^{1}$ Each of the original V-Dem indicators are coded by a minimum of five experts per country-year, who typically give their responses to questions on ordinal five-point scales. Subsequently, using a Bayesian item response theory model, V-Dem aggregates the experts' responses into one indicator-country-year observation. By weighing each coder by a reliability parameter that is in part determined by their level of agreement with the other country coders, this model accounts for differential item functioning and ensures cross-coder consistency and intertemporal and cross-country comparability (Coppedge et al. 2019a; Pemstein et al. 2019).

${ }^{2}$ Specifically, this variable (as well as the other clientelism indicator used in this analysis) is constructed by linearly mapping onto an interval scale the ordinal posterior predictions that the estimate falls in one of the five categories of the original ordinal scale. To give an example of how this interval should be interpreted, take a value of 1.8 for the vote buying indicator (i.e. the value recorded in Thailand in 1992). This indicates that the median measurement model posterior predicted value is closer to the ordinal value of 2 (restricted evidence of vote buying: money and/or personal gifts are distributed by parties or candidates but these offerings are more about meeting an 'entry ticket' expectation and less about actual vote choice or turnout) than to the value of 1 (non-systematic but rather common vote buying efforts).
} 

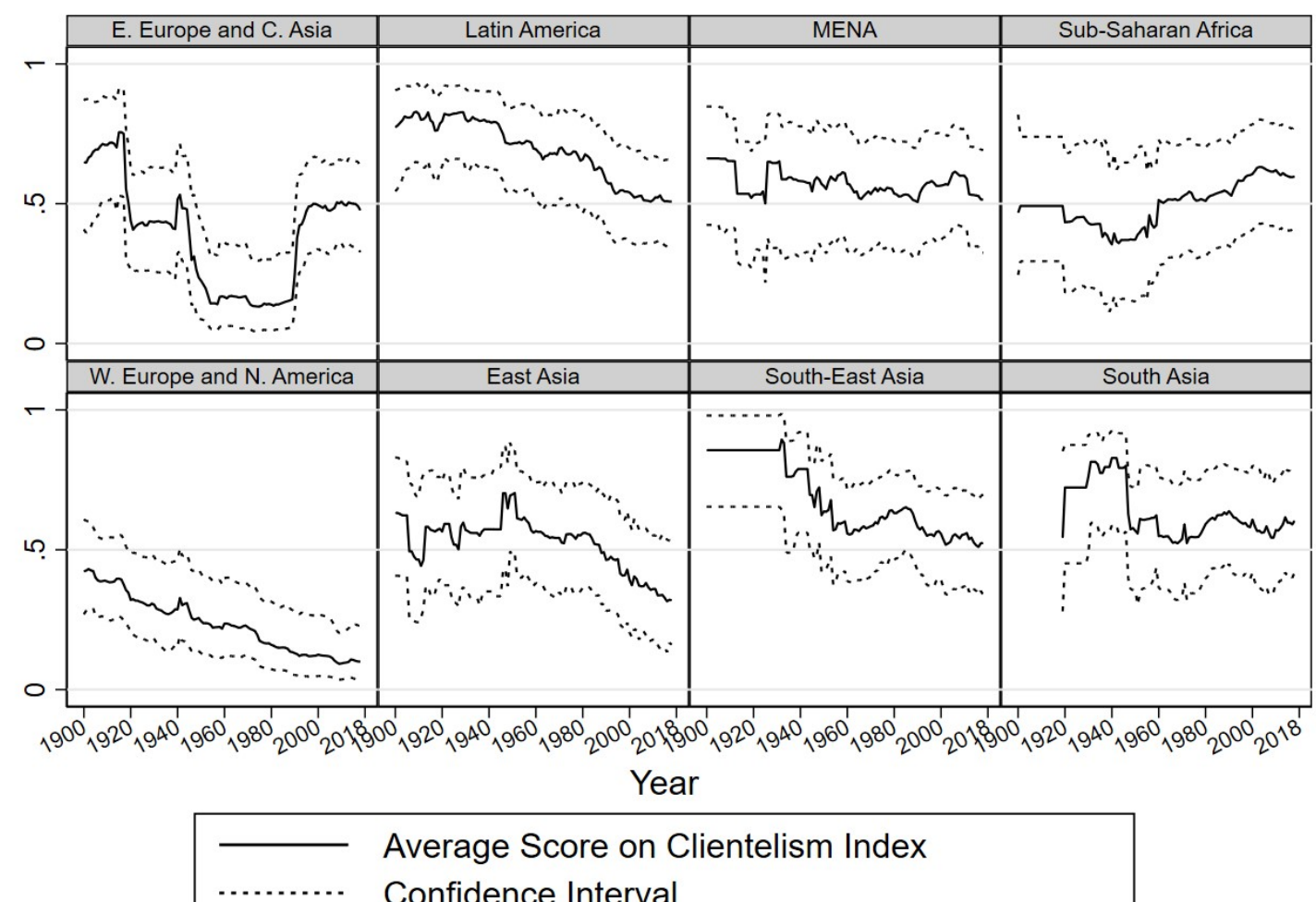

Note: higher values of the index correspond to more political clientelism.

Source: authors' elaboration based on the V-Dem data set (Coppedge et al. 2019b).

and (4) 'policy/programmatic' (i.e. constituents respond to a party's positions on national policies, general party programmes, and visions for society).

This paper seeks to analyse the effects of clientelistic practices in politics on public goods provision, and uses as key (alternative) independent variables the 'vote buying' and 'party linkages' indicators, as well as the aggregate index of clientelism.

Figure 1 shows that, throughout the twentieth century, clientelistic practices have followed diverse patterns across regions. In two regions (Latin America and South-East Asia) we find a steep decline in political clientelism from very high levels. The South Asian record declines over some periods of time and mildly increases or stagnates in others, resulting in small changes from the values observed in 1900 to those observed in the most recent years. Since the 1980s, clientelism has gradually increased in SubSaharan Africa. Conversely, over the same time period it has declined in East Asia. Eastern Europe and Central Asia have gone through a U-shaped trend, with a sharp decline up to the 1960s, followed by stagnation during the Soviet regime and by an upward trend in the 1990s that stabilized only in the most recent years. Last, Western Europe and North America display the lowest levels of political clientelism and a gradual decline. 
Behind these average trends, there are varying patterns for each of the two subcomponents of the clientelism index. For these variables we use the linearized original scale posterior prediction' version of the related indicators, which are computed as the sum of the posterior probabilities that the estimate is in one of the five categories as originally coded (Coppedge et al. 2019a; Pemstein et al. 2019).

In Sub-Saharan Africa the relative increase of political clientelism displayed in Figure 1 mainly results from a steep increase in vote-buying practices (Figure 2). Conversely, in the MENA (Middle East and North Africa) region, we observe a steep reduction (i.e. a more clientelistic relationship between parties and the constituents) in the party linkage indicator up to the mid-1970s (Figure 3). In South Asia and in South-East Asia, vote-buying practices do not show any substantial sign of improvement over time. Until recently, these two regions appear as the worst-performing regions in the vote-buying dimension of political clientelism. Political patronage in the party-constituents relationship appears, instead, particularly problematic in Latin America. Despite some mild improvements over the twentieth century, this region nowadays records an average score of 2 in the related indicator (i.e. parties tend

Figure 2: Historical trends in vote buying in eight world regions
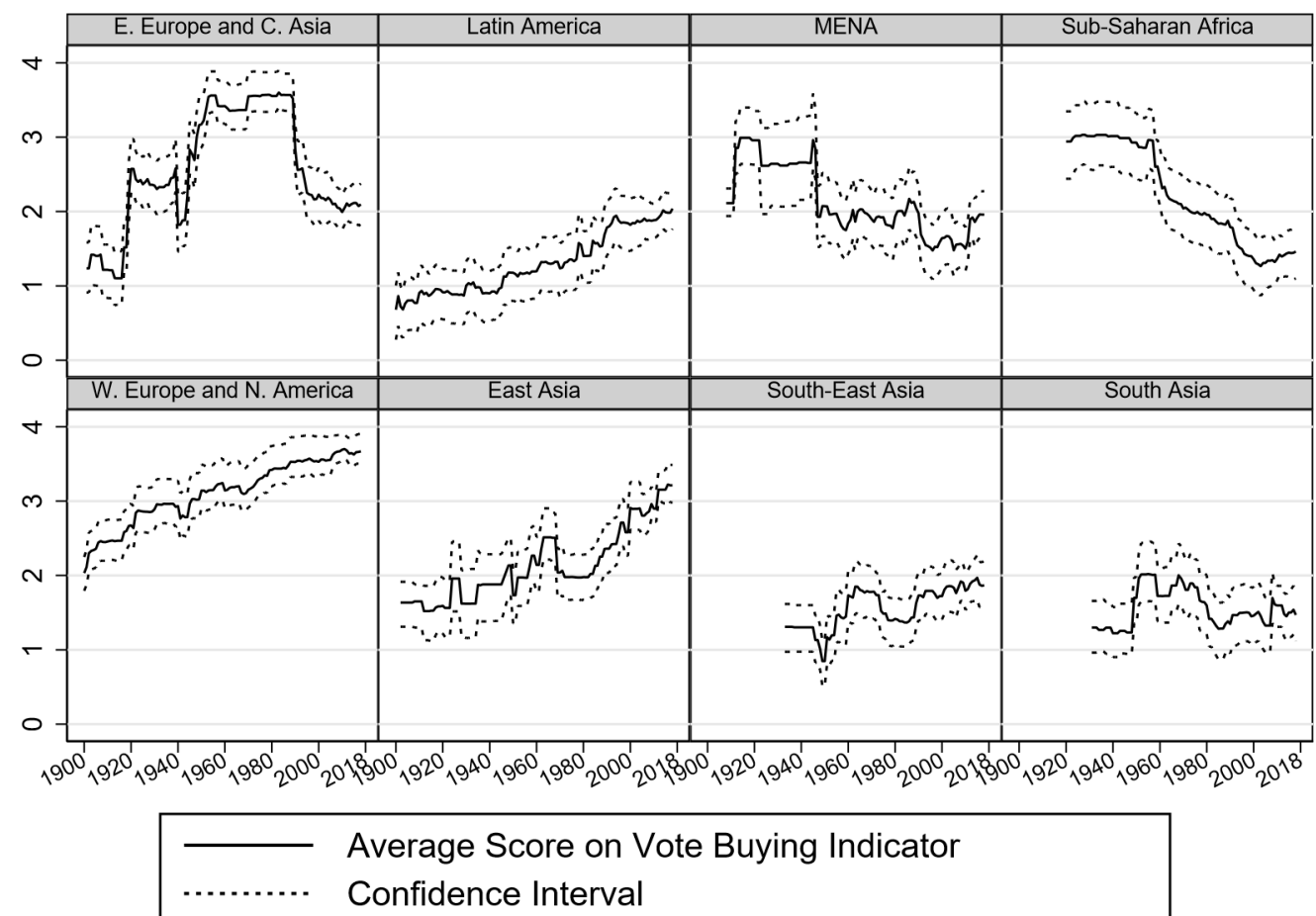

Note: higher values of the index correspond to less vote buying.

Source: authors' elaboration based on the V-Dem data set (Coppedge et al. 2019b). 
Figure 3: Historical trends in clientelistic party linkages in eight world regions

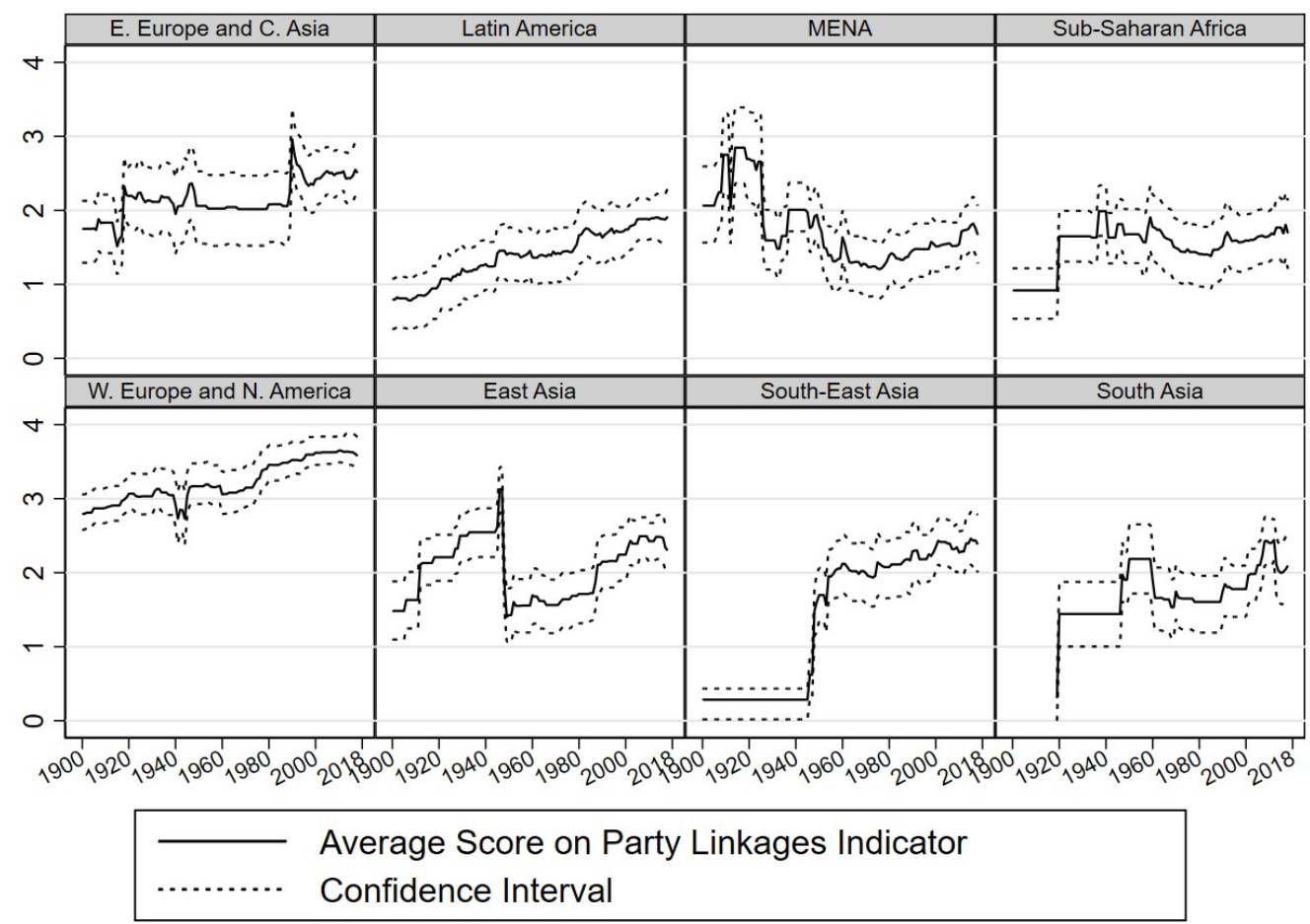

Note: higher values of the index correspond to less clientelistic party linkages.

Source: authors' elaboration based on the V-Dem data set (Coppedge et al. 2019b).

to reward constituents with local collective goods). This is similar to the type of political patronage observed in poorer countries of Sub-Saharan Africa and MENA region.

\subsection{Dependent variables}

We focus on three key dependent variables: universalism of welfare programmes, corruption, and rule of law. The first variable is a proxy for the state's ability to implement universal social policies and to effectively provide public goods (e.g., free education, health care schemes, retirement and unemployment allowances) through programmes that potentially benefit everyone. Specifically, the V-Dem indicator of the universalism of welfare programmes assesses the extent to which welfare state policies tend to be means-tested or universal in their coverage. The focus here is not on the size of the welfare state per se, but rather on its quality. The indicator is an interval measure on a scale from 0 to 5 , mapping onto the original coding criteria for the experts' assessment of the universalism of welfare programmes. The original categories range from (0) 'There are no, or extremely limited, welfare state policies' to (5) 'Almost all welfare state policies are universal in character. Only a small portion is means-tested.' 
In order to test our second hypothesis, that clientelism leads to weaker governance quality, we use as dependent variables the political corruption and the rule of law indices from the V-Dem database. The political corruption index is formed by taking the point estimates from a Bayesian factor analysis model using six indicators: executive bribery, executive embezzlement, public sector bribery, public sector embezzlement, legislative corruption, and judicial corruption. ${ }^{3}$ The index, which is grounded on the definition of corruption as the use of public office for private gain, excludes electoral irregularities (such as vote buying) and political patronage. Whereas vote buying and clientelistic party linkages might be perceived as a form of corruption for the 'irregular' use of resources that they entail, they are substantially different from political corruption. Here the distinguishing feature is the identity of the subjects related to clientelistic practices and to political corruption. Electoral frauds and clientelistic rewards to constituents are typically carried by individuals (brokers) or organizations (political parties). Political corruption instead involves executives (heads of government and state and cabinet ministers), legislators, judges, and bureaucrats.

The rule of law index measures the extent to which laws are transparently, independently, predictably, impartially, and equally enforced, and to which the actions of government officials comply with the law. The index is formed by taking the point estimates from a Bayesian factor analysis model of the following indicators: compliance with high court, compliance with judiciary, high court independence, lower court independence, the executive respects the constitution, rigorous and impartial public administration, transparent laws with predictable enforcement, access to justice for men, access to justice for women, judicial accountability, judicial corruption decisions, public sector corrupt exchanges, public sector theft, executive bribery and corrupt exchanges, and executive embezzlement and theft.

It is worth noting that, according to this definition and this way of measuring the index, corruption appears as one dimension of rule of law. ${ }^{4}$ In this sense, the rule of law index can be understood as a more generally proxy for governance quality.

In Table 1 we report the average values of our measures of political clientelism by quartiles or by category of the dependent variable. From this descriptive exercise, it clearly Table 1: Average values of the political clientelism index and of its sub-components by quartiles of the dependent variable

\footnotetext{
${ }^{3}$ An extensive discussion regarding the validity of the V-Dem political corruption index is provided by McMann et al. 2021.

${ }^{4}$ Namely, most of the indicators used for the computation of the corruption index (i.e. executive bribery, executive embezzlement, public sector bribery and embezzlement, and judicial corruption) are also entered for the computation of the rule of law index.
} 


\begin{tabular}{llcccc}
\hline & & $\begin{array}{c}\text { Political } \\
\text { clientelism } \\
\text { index }\end{array}$ & $\begin{array}{c}\text { Vote } \\
\text { buying }\end{array}$ & $\begin{array}{c}\text { Party } \\
\text { linkages }\end{array}$ & N \\
\hline Universal welfare programmes & First quartile & 0.698 & 1.382 & 1.397 & 3,269 \\
& Second quartile & 0.516 & 1.943 & 2.136 & 3,269 \\
& Third quartile & 0.442 & 2.226 & 2.090 & 3,269 \\
& Fourth quartile & 0.320 & 2.758 & 2.406 & 3,269 \\
Corruption & First quartile & 0.203 & 3.274 & 3.152 & 3,264 \\
& Second quartile & 0.455 & 2.260 & 2.081 & 3,271 \\
& Third quartile & 0.581 & 1.732 & 1.573 & 3,244 \\
Rule of Law & Fourth quartile & 0.738 & 1.117 & 1.190 & 3,269 \\
& First quartile & 0.687 & 1.422 & 1.228 & 3,258 \\
& Second quartile & 0.599 & 1.686 & 1.661 & 3,276 \\
& Third quartile & 0.491 & 1.962 & 1.887 & 3,285 \\
& Fourth quartile & 0.202 & 3.203 & 3.244 & 3,275 \\
\hline
\end{tabular}

Source: authors' elaboration based on the V-Dem data set (Coppedge et al. 2019b).

emerges that there is a negative (positive) gradient between corruption (rule of law) and political clientelism. Observations in the lowest (highest) quartile of the corruption (rule of law) distribution record on average a score of 3 in the two indicators of political clientelism, implying limited use of vote buying and a tendency for programmatic responses of parties to their constituents. On the contrary, in most corrupt countries and in countries with the weakest rule of law the mean values are around 1-that is, there is on average common use of vote buying practices and parties are linked to constituents who are rewarded by the parties with clientelistic and local collective goods. We moreover observe that countries with the largest number of universal welfare programmes tend also to exhibit less vote buying and more programmatic party- constituents linkages. However, looking at the distribution of countries along the universal programmes indicator, the differences in the average values of the political clientelism index and indicators along the second and third quartiles appear substantively insignificant compared to the case of the two governance quality indices.

\section{Empirical analysis}

\subsection{Empirical strategy}

Our benchmark econometric model is formalized as:

$$
y_{c, t}=\beta 0+\beta 1 \text { Client }_{c, t-1}+\beta 2 \ln P o p_{c, t}+\beta 3 \ln G D P_{c, t}+\tau_{t}+\mu_{c}+u_{c, t}(1)
$$


where for each country $c$, observed in year $t, y$ is one of our key three outcome variables of interest (universal welfare programmes, corruption, rule of law); Client is the political clientelism index or one of its components (vote buying, party linkages) measured in the precedent year and $\ln P o p$ and $\ln G D P$ are the $\log$ of population and of GDP per capita. We include country fixed effects $\left(\mu_{c}\right)$, accounting for country-specific time-invariant factors (e.g., culture, ethnic composition, colonial history) that can affect simultaneously political clientelism, corruption, and social policy. Time fixed effects $\left(\tau_{t}\right)$ instead allow us to control for global time trends and common 'shocks' (e.g., world wars, global economic depressions) as well as country-time specific events (such as years of elections or ratification of international conventions and laws).

Further, we extend this baseline model with two additional specifications. First, we control for countries' levels and experience of democracy by adding the one-year-lagged value of the electoral democracy index from V-Dem, ${ }^{5}$ its quadratic form, and a variable called 'stock of democracy' which is computed as the sum of the value of electoral democracy at time $t$ and at time $t-1$, minus 10 per cent of depreciation at time $t-1$, which discounts more distant history of democracy. We introduce the stock of democracy as an additional control along with the current level of democracy (which is a flow measure) as the democratic stock provides additional information on the country's political history that is not captured by the present level of democracy or regime type (Edgell et al. 2020). The introduction of democracy and its quadratic specification allows us to control for the non-linearities in the relationship between democracy and our dependent variables. As argued in the extensive review of literature conducted by McMann et al. (2020), it has been increasingly observed that highly democratic and autocratic countries seem to experience low corruption levels. Instead, high corruption levels are associated with modest levels of democracy. Similarly, encompassing social policies and public goods provisions may not necessarily linearly increase with democracy.

Empirical research on the relationship between democracy and public goods provision has predominantly reported positive effects (e.g., Bueno De Mesquita 2003; Deacon 2009; Lake and Baum 2001). However, the literature is still inconclusive and many scholars have argued that it is experience with democratic institutions that secures public goods provision that matters rather than the current level of democracy (e.g., Gerring et al. 2012; Keefer 2007; McGuire 2010; Min 2015). The introduction of the 'stock of democracy' variable allows us

\footnotetext{
${ }^{5}$ For more discussion of this index, see Teorell et al. (2019).
} 
to control for the mediating effect of the age of democracy in shaping the relationship between our key dependent variables and democracy.

In order to mitigate omitted variable bias, we estimate a third specification that includes five additional time-varying control variables to control for exposure to trade ('openness') and other external shocks ('civil war'), ${ }^{6}$ countries' level of socioeconomic development (proxied by life expectancy and by average years of the education of the adult population), and inequality (proxied by rural inequality). ${ }^{7}$

\subsection{Main results}

The main results of the analysis are presented in Tables $2-4$. The specifications of Table 2 speak to our first hypothesis-that is, clientelistic practices distort incentives, which perpetuate after elections in forms of unequal and inefficient redistribution by the ruling parties. This leads to the under-provision of public goods.

Our results suggest that political clientelism reduces the universality of welfare programmes. The estimated coefficient of -1.78 of the baseline model implies that the difference between the least clientelistic country (i.e. Portugal in 2017, scoring 0.03) and one of the most clientelistic countries of our sample (i.e. Nicaragua in 1975, scoring 0.97) corresponds on average to a reduction by 1.78 units in the universal programmes indicator (moving, for example, from a context where all welfare policies are universal to a context where half of these policies are means-tested).

Interestingly, the effect of political clientelism on public goods provision significantly differs according to the political regime. Splitting the sample according to the dichotomy 'closed or electoral autocracies versus electoral and liberal democracies' (see Table B2 in Appendix B), we observe that political clientelism seems to significantly undermine public good provision in electoral autocracies, ${ }^{8}$ but not in countries that feature de facto free and

\section{Table 2: Clientelism and universalism of welfare programmes}

\footnotetext{
${ }^{6}$ For a detailed description and summary statistics of the control variables, see Appendix A and Table B1 of Appendix B.

${ }^{7}$ As a measure of inequality, we use the Vanhanen's share of family farms as a proxy for land inequality. This variable, which - contrary to the Gini index - is measured starting from the beginning of the twentieth century, allows us to keep our sample as large as possible. However, the inclusion of this variable and of 'civil war', which are available only up to 2006, restricts our time span to the period 1901-2006.

${ }^{8}$ These are countries with de jure multiparty elections but which fail to achieve free and fair elections, or de facto multiparty, or a minimum level of Dahl's institutional prerequisites of polyarchy.
} 


\begin{tabular}{|c|c|c|c|}
\hline & (1) & (2) & (3) \\
\hline \multirow[t]{2}{*}{ Clientelism index $\mathrm{x}_{\mathrm{t}-1}$} & $-1.781 * * *$ & $-1.739 * * *$ & $-1.692 * * *$ \\
\hline & $(-32.669)$ & $(-31.697)$ & $(-24.636)$ \\
\hline \multirow[t]{2}{*}{ Ln population } & $0.403^{* * *}$ & $0.295^{* * *}$ & $0.152^{* * *}$ \\
\hline & $(17.738)$ & $(11.831)$ & $(3.855)$ \\
\hline \multirow[t]{2}{*}{ Ln GDP per capitat-1 } & $0.066^{* * *}$ & $0.060 * * *$ & $0.166^{* * *}$ \\
\hline & $(3.855)$ & $(3.545)$ & $(6.592)$ \\
\hline \multirow[t]{2}{*}{ Electoral democracyt-1 } & & $-2.292 * * *$ & $-1.908^{* * *}$ \\
\hline & & $(-8.631)$ & $(-6.244)$ \\
\hline \multirow[t]{2}{*}{ Electoral democracy ${ }^{2}$} & & $-1.652^{* * *}$ & $-1.089 * * *$ \\
\hline & & $(-10.496)$ & $(-5.477)$ \\
\hline \multirow[t]{2}{*}{ Stock of democracy } & & $2.296^{* * *}$ & $1.745^{* * *}$ \\
\hline & & $(12.462)$ & $(7.862)$ \\
\hline Openness & & & $\begin{array}{r}-0.004 * * * \\
(-5.436)\end{array}$ \\
\hline Education & & & $\begin{array}{c}0.048^{* * *} \\
(3.364)\end{array}$ \\
\hline Life expectancy & & & $\begin{array}{c}0.006^{* * *} \\
(2.975)\end{array}$ \\
\hline Rural Inequality & & & $\begin{array}{c}0.009^{* * *} \\
(13.583)\end{array}$ \\
\hline Civil war & & & $\begin{array}{c}-0.135^{* * *} \\
(-4.147)\end{array}$ \\
\hline \multirow[t]{2}{*}{ Constant } & $-2.424 * * *$ & $-1.741 * * *$ & $-1.682^{* * *}$ \\
\hline & $(-6.828)$ & $(-4.749)$ & $(-3.225)$ \\
\hline Observations & 11,030 & 10,984 & 7,294 \\
\hline R-squared & 0.797 & 0.804 & 0.835 \\
\hline Number of country_id & 161 & 161 & 126 \\
\hline Country FE & Yes & Yes & Yes \\
\hline Year FE & Yes & Yes & Yes \\
\hline Time period & 1901-2017 & $1901-2017$ & 1901-2006 \\
\hline
\end{tabular}

Note: OLS with panel corrected standard errors. $t$-values reported in parentheses. ${ }^{*} p<0.1,{ }^{* *} p<0.05$, ${ }^{* * *} p$ $<0.01$.

Source: authors' elaboration based on the V-Dem data set (Coppedge et al. 2019b).

fair multiparty elections (liberal and electoral democracies). This is corroborated by the more general finding in the literature of a curve-linear relationship between corruption and democracy (McMann et al. 2020). Higher levels of democracy with freer media and independent judiciaries should make it harder to pursue illicit strategies such as vote buying 
Table 3: Clientelism and corruption

\begin{tabular}{|c|c|c|c|}
\hline & (1) & (2) & (3) \\
\hline \multirow[t]{2}{*}{ Clientelism index $\mathrm{x}_{\mathrm{t}-1}$} & $0.420^{* * *}$ & $0.379 * * *$ & $0.289^{* * *}$ \\
\hline & $(51.471)$ & $(45.139)$ & $(28.629)$ \\
\hline \multirow[t]{2}{*}{ Ln population } & $0.014 * * *$ & -0.001 & -0.007 \\
\hline & $(4.315)$ & $(-0.286)$ & $(-1.228)$ \\
\hline \multirow[t]{2}{*}{ Ln GDP per capitat- 1} & $-0.027 * * *$ & $-0.024 * * *$ & $-0.027^{* * *}$ \\
\hline & $(-10.170)$ & $(-9.090)$ & $(-7.224)$ \\
\hline \multirow[t]{2}{*}{ Electoral democracyt -1} & & 0.056 & 0.024 \\
\hline & & $(1.451)$ & $(0.564)$ \\
\hline \multirow[t]{2}{*}{ Electoral democracy $^{2}$} & & $-0.205^{* * *}$ & $-0.165^{* * *}$ \\
\hline & & $(-9.018)$ & $(-6.246)$ \\
\hline \multirow[t]{2}{*}{ Stock of democracy } & & -0.008 & -0.017 \\
\hline & & $(-0.304)$ & $(-0.569)$ \\
\hline Openness & & & $\begin{array}{r}0.000 \\
(0.537)\end{array}$ \\
\hline Education & & & $\begin{array}{c}0.008^{* * * *} \\
(3.496)\end{array}$ \\
\hline Life expectancy & & & $\begin{array}{c}-0.000 \\
(-0.018)\end{array}$ \\
\hline Rural inequality & & & $\begin{array}{c}0.000^{* * * *} \\
(4.081)\end{array}$ \\
\hline Civil war & & & $\begin{array}{r}-0.000 \\
(-0.008)\end{array}$ \\
\hline \multirow[t]{2}{*}{ Constant } & 0.012 & $0.211 * * *$ & $0.263^{* * *}$ \\
\hline & $(0.231)$ & $(4.076)$ & $(3.525)$ \\
\hline Observations & 10,996 & 10,950 & 7,294 \\
\hline R-squared & 0.913 & 0.917 & 0.935 \\
\hline Number of country_id & 161 & 161 & 126 \\
\hline Country FE & Yes & Yes & Yes \\
\hline Year FE & Yes & Yes & Yes \\
\hline Time period & $1901-2017$ & $1901-2017$ & 1901-2006 \\
\hline
\end{tabular}

Note: OLS with panel corrected standard errors. $t$-values reported in parentheses. ${ }^{*} p<0.1,{ }^{* *} p<0.05,{ }^{* * *} p$ $<0.01$.

Source: authors' elaboration based on the V-Dem data set (Coppedge et al. 2019b).

in particular, but also more targeted 'club' goods provision and particularistic spending patterns. Moreover, confirming previous findings from Keefer (2007), it appears that experience with democracy matters for a more universal provision of welfare programmes. The longer is the country's historical experience with democracy (higher levels of stock of democracy), the largest the universality of welfare programmes tends to be. In younger 
Table 4: Clientelism and rule of law

\begin{tabular}{|c|c|c|c|}
\hline & (1) & (2) & (3) \\
\hline \multirow[t]{2}{*}{ Clientelism index $\mathrm{x}_{\mathrm{t}-1}$} & $-0.312^{* * *}$ & $-0.201 * * *$ & $-0.155^{* * *}$ \\
\hline & $(-31.537)$ & $(-26.321)$ & $(-16.612)$ \\
\hline \multirow[t]{2}{*}{ Ln population } & 0.008 & -0.003 & 0.006 \\
\hline & $(1.626)$ & $(-0.669)$ & $(1.168)$ \\
\hline \multirow[t]{2}{*}{ Ln GDP per capitat-1 } & $0.051 * * *$ & $0.034 * * *$ & $0.040^{* * *}$ \\
\hline & (15.833) & $(14.006)$ & (12.293) \\
\hline \multirow[t]{2}{*}{ Electoral democracy $\mathrm{t}-1$} & & $-0.666^{* * *}$ & $-0.726^{* * *}$ \\
\hline & & $(-17.463)$ & $(-18.411)$ \\
\hline \multirow[t]{2}{*}{ Electoral democracy $^{2}$} & & $-0.266^{* * *}$ & $-0.358^{* * *}$ \\
\hline & & $(-11.938)$ & $(-14.687)$ \\
\hline \multirow[t]{2}{*}{ Stock of democracy } & & $0.785^{* * *}$ & $0.868^{* * *}$ \\
\hline & & $(30.097)$ & $(31.231)$ \\
\hline Openness & & & $\begin{array}{c}0.001 * * * \\
(4.323)\end{array}$ \\
\hline Education & & & $\begin{array}{c}-0.020^{* * *} \\
(-10.150)\end{array}$ \\
\hline Life expectancy & & & $\begin{array}{c}-0.002 * * * \\
(-5.576)\end{array}$ \\
\hline Rural inequality & & & $\begin{array}{r}0.000 \\
(0.353)\end{array}$ \\
\hline Civil war & & & $\begin{array}{c}-0.009^{* *} \\
(-1.987)\end{array}$ \\
\hline \multirow[t]{2}{*}{ Constant } & $0.529 * * *$ & $0.409 * * *$ & $0.439 * * *$ \\
\hline & $(7.413)$ & $(7.753)$ & $(6.349)$ \\
\hline Observations & 11,031 & 10,985 & 7,295 \\
\hline R-squared & 0.874 & 0.932 & 0.949 \\
\hline Number of country_id & 161 & 161 & 126 \\
\hline Country FE & Yes & Yes & Yes \\
\hline Year FE & Yes & Yes & Yes \\
\hline Time period & $1901-2017$ & $1901-2017$ & 1901-2006 \\
\hline
\end{tabular}

Note: OLS with panel corrected standard errors. $t$-values reported in parentheses. ${ }^{*} p<0.1,{ }^{* *} p<0.05$, ${ }^{* * *} p$ $<0.01$.

Source: authors' elaboration based on the V-Dem data set (Coppedge et al. 2019b).

democracies, as argued by Keefer and Vlaicu (2008), political competitors are more likely to face a problem of credibility, which would provide them with incentives to make credible promises only to small segments of the electorate, pursuing therefore high targeted spending, high rent-seeking, and low public goods provision. 
We now turn to the second hypothesis: political clientelism generates incentives for weakening the enforcement of the law. As argued by Holland (2016), forbearance with respect to violations of law represents a valuable reward for many constituents (especially those with the poorest socioeconomic background). These incentives will therefore lead to increased corruption and to weaker rule of law. Our main results, shown in Tables 3 and 4, suggest that clientelistic practices in politics lead to more corruption and less rule of law. According to the specifications displayed in columns 2 and 3, the difference between minimum and maximum on the political clientelism index (i.e. the index goes from 0 to 1 ) is associated with a difference in the rule of law index by around 20 to 15 per cent and a difference on the corruption index by around 38 to 29 per cent. These are rather large magnitudes, corresponding, for example, to the difference in corruption levels between Denmark in 2012 (one of the least corrupt country-year observations in our sample) and Turkey or Argentina in the 1980s. Analogously, a 20 per cent increase in the rule of law index is comparable to the difference between Chile in 1924 (when the country experienced political instability leading to the end of its pseudo- parliamentary system) and Italy in 2016 (one of the observations in the top 20 per cent of the distribution of the rule of law index).

Our next step is to investigate which dimensions of political clientelism matter the most in driving the results shown above. For presentation reasons, we report in Table 5 the coefficients on the party linkages and on the vote-buying indicators obtained relying on the same models and specifications illustrated in Tables $2-4$.

The estimated coefficients that are comparable, in terms of statistical significance, to the coefficients on the political clientelism index suggest that non-programmatic party linkages and vote buying are equally important in driving the negative relationship between political clientelism and corruption, and between political clientelism and universalism of welfare programmes.

On the other hand, clientelistic ties between parties and their constituents seem to exert - compared to vote buying — a relative larger influence on countries' rule of law. A oneunit difference in the party linkages indicator (e.g. moving from non-clientelistic party linkages to a mix of programmatic and local collective rewards in the party-constituents relationship) decreases the rule of law index by 10 to 5 per cent, which accounts for about one-third of the total effect of the political clientelism index. This result may be explained by the fact that while vote buying and party linkages may be seen as clientelistic strategies that are supplementary to each other by politicians to obtain electoral support from a set of voters, they differ in the timing of the clientelist exchange, which may have implications for how 
Table 5: Overview on the coefficients on 'party linkages' and 'vote buying' across different specifications of the baseline and controls models

\begin{tabular}{lcc}
\hline & Party Linkages & Vote buying \\
\hline Panel A: Universal welfare programmes & $0.248^{* * *}$ & $0.265^{* * *}$ \\
Baseline & $0.186^{* * *}$ & $0.259^{* * *}$ \\
M1 & $0.172^{* * *}$ & $0.288^{* * *}$ \\
M2 & $-0.092^{* * *}$ & $-0.089^{* * *}$ \\
\hline Panel B: Corruption & $-0.082^{* * *}$ & $-0.081^{* * *}$ \\
Baseline & $-0.063^{* * *}$ & $-0.062^{* * *}$ \\
M1 & $0.102^{* * *}$ & $0.052^{* * *}$ \\
M2 & $0.058^{* * *}$ & $0.033^{* * *}$ \\
\hline Panel C: Rule of Law & $0.050^{* * *}$ & $0.028^{* * *}$ \\
Baseline & & \\
M1 & & \\
M2 & &
\end{tabular}

Note: $* p<0.1, * * p<0.05, * * * p<0.01$.

Source: authors' elaboration based on the V-Dem data set (Coppedge et al. 2019b).

these two strategies affect the rule of law. The first strategy—vote buying-involves a preelection transfer to induce citizens to vote for the party. The second strategy-party linkages - captures the post-election delivery of goods and services conditional on political support in the election. While both strategies are expected to have similar negative effects on corruption, the post-election delivery of goods and services to specific voters in return for political support delays the building of an impersonal bureaucracy, with well-defined rules and modes of functioning (Bardhan 2021). This implies that the effect of political clientelism through party linkages may have a larger negative effect on the rule of law than through vote buying.

Finally, we investigate if and to what extent the assessed relationship between political clientelism, governance, and public goods provision varies across different country contexts. We start by considering the geopolitical classification of our countries and run our benchmark models separately for six regions of the world. Considering the econometric specification with control variables ('M2'), the results provided in Table 6 show that the bulk of the negative effect of political clientelism on the universality of welfare programmes is mainly driven by the historical experience of Western countries. Yet, the effects on governance quality appear substantially smaller if compared to other regions of the world.

Relative to other regions of the world, East Asia, Sub-Saharan Africa, and MENA regions exhibit the largest coefficients on political clientelism in the regressions with corruption. For instance, in SubSaharan Africa, a 100 per cent reduction in the index of 
Table 6: Assessing heterogeneity by regions: an overview of the coefficients on the political clientelism index across different specifications of the baseline and controls models

\begin{tabular}{|c|c|c|c|c|c|c|}
\hline & $\begin{array}{l}\text { Eastern } \\
\text { Europe } \\
\text { and } \\
\text { Central } \\
\text { Asia }\end{array}$ & $\begin{array}{c}\text { Latin } \\
\text { America } \\
\text { and the } \\
\text { Caribbean }\end{array}$ & $\begin{array}{c}\text { Sub- } \\
\text { Saharan } \\
\text { Africa } \\
\text { and } \\
\text { MENA }\end{array}$ & $\begin{array}{c}\text { West } \\
\text { Europe } \\
\text { and } \\
\text { North } \\
\text { America }\end{array}$ & East Asia & $\begin{array}{l}\text { South } \\
\text { Asia and } \\
\text { South- } \\
\text { East Asia }\end{array}$ \\
\hline $\begin{array}{l}\text { Panel A: Universal } \\
\text { welfare programmes }\end{array}$ & & & & & & \\
\hline Baseline & $-0.800 * * *$ & $-1.130^{* * *}$ & $-1.733 * * *$ & $-3.012^{* * *}$ & $-3.109 * * *$ & $-1.690 * * *$ \\
\hline M1 & $-0.804^{* * *}$ & $-1.124^{* * *}$ & $-1.542^{* * *}$ & $-2.101 * * *$ & $-4.225^{* * *}$ & $-1.678^{* * *}$ \\
\hline M2 & $-0.391 * * *$ & $-1.100^{* * *}$ & $-0.954^{* * *}$ & $-3.144 * * *$ & $-1.380^{*}$ & -0.088 \\
\hline $\begin{array}{l}\text { Panel B: Corruption } \\
\text { Baseline }\end{array}$ & $0.625^{* * *}$ & $0.305^{* * *}$ & $0.400^{* * *}$ & $0.377 * * *$ & $0.569 * * *$ & $0.305^{* * *}$ \\
\hline M1 & $0.391 * * *$ & $0.288^{* * *}$ & $0.367 * * *$ & $0.227 * * *$ & $0.925^{* * *}$ & $0.287^{* * *}$ \\
\hline M2 & $0.264^{* * *}$ & $0.271 * * *$ & $0.321^{* * *}$ & $0.138^{* * *}$ & $0.495^{* * *}$ & $0.289 * * *$ \\
\hline $\begin{array}{l}\text { Panel C: Rule of } \\
\text { Law }\end{array}$ & & & & & & \\
\hline Baseline & $-0.321^{* * *}$ & $-0.300^{* * *}$ & $-0.408^{* * *}$ & $-0.599 * * *$ & $-0.467 * * *$ & $-0.338^{* * *}$ \\
\hline M1 & 0.035 & $-0.157^{* * *}$ & $-0.317^{* * *}$ & $-0.202^{* * *}$ & $-0.279 * * *$ & $-0.318^{* * *}$ \\
\hline M2 & -0.027 & $-0.180^{* * *}$ & $-0.270^{* * *}$ & $-0.157^{* * *}$ & -0.181 & $-0.326^{* * *}$ \\
\hline
\end{tabular}

Note: $* p<0.1, * * p<0.05, * * * p<0.01$.

Source: authors' elaboration based on the V-Dem data set (Coppedge et al. 2019b).

political clientelism would correspond to a 32 per cent reduction in the corruption index. For the average observation in the regional sample, which is associated with a value of the corruption index of around 0.59 , this reduction would imply an improvement in corruption levels similar to the ones observed at the mean of the distribution of Western countries over the last 30 years.

Lastly, in South Asia and South-East Asia, two regions that despite the declining trend in political patronage did not show any improvement in reducing the widespread use of votebuying practices, political clientelism seems to have not significantly reduced the provision of public goods. Yet, it has substantially undermined rule of law.

Similar patterns emerge when splitting the sample according to the level of endowments of natural resources, where the experience of non-resource-rich countries resembles the above-discussed results pertaining to Western countries (see Table 7). On the other hand, we also observe that the effects of political clientelism on corruption have been quite similar in the two groups of countries.

Finally, we check whether the effects of political clientelism systematically differ in countries according to their levels of inequality by splitting the sample at the median of the 
Table 7: Assessing heterogeneity by level of resource endowment: overview of the coefficients on the political clientelism index across different specifications of the baseline and control models

\begin{tabular}{lcc}
\hline & $\begin{array}{c}\text { Resource-endowed } \\
\text { countries }\end{array}$ & $\begin{array}{c}\text { Non-resource-endowed } \\
\text { countries }\end{array}$ \\
\hline $\begin{array}{l}\text { Panel A: Universal Welfare Programmes } \\
\text { Baseline }\end{array}$ & $-1.265^{* * *}$ & $-2.124^{* * *}$ \\
M1 & $-1.264^{* * *}$ & $-2.067^{* * *}$ \\
M2 & $-1.531^{* * *}$ & $-1.712^{* * *}$ \\
\hline Panel B: Corruption & $0.389^{* * *}$ & $0.369^{* * *}$ \\
Baseline & $0.350^{* * *}$ & $0.338^{* * *}$ \\
M1 & $0.274^{* * *}$ & $0.344^{* * *}$ \\
M2 & $-0.212^{* * *}$ & $-0.388^{* * *}$ \\
\hline Panel C: Rule of Law & $-0.135^{* * *}$ & $-0.297^{* * *}$ \\
Baseline & $-0.109^{* * *}$ & $-0.286^{* * *}$ \\
M1 &
\end{tabular}

Note: resource-endowed (non-endowed) countries are countries above (below) the median sample value (29.875) of resources endowment (i.e. real value of petroleum, coal, natural gas, and metals production per capita). $* p<0.1, * * p<0.05, * * * p<0.01$.

Source: authors' elaboration based on the V-Dem data set (Coppedge et al. 2019b).

Vanhanen's share of family farms (Vanhanen 1997), a proxy for land inequality. In countries with high inequality, parties might be expected to encounter greater obstacles to consolidating relationships with their large pool of lowincome constituents and in redistributing benefits of all forms on a larger scale, as this would affect the status quo that the powerful elite at the top of the distribution wants to maintain (Robinson and Verdier 2013).

On the other hand, political clientelism can have a greater reductive effect on public goods provisions in more unequal societies. In this context, indeed, a large pool of landless, poor, and low-educated people is expected to be particularly prone to providing political support to leaders in exchange for small gifts and tiny 'club goods' (Bardhan and Mookherjee 2006; Markussen 2011). This latter hypothesis is supported by our empirical estimations. As our results indicate, the universality of welfare programmes appears much more affected by political clientelism in countries with higher levels of rural inequality. In this set of countries we observe, moreover, a relatively larger impact of political clientelism on corruption and rule of law (see Table 8). 
Table 8: Assessing heterogeneity by level of rural inequality: overview of the coefficients on the political clientelism index across different specifications of the baseline and control models

\begin{tabular}{|c|c|c|}
\hline & $\begin{array}{l}\text { High rural inequality } \\
\text { countries }\end{array}$ & $\begin{array}{c}\text { Low rural inequality } \\
\text { countries }\end{array}$ \\
\hline \multicolumn{3}{|l|}{ Panel A: Universal Welfare Programmes } \\
\hline Baseline & $-1.907 * * *$ & $-0.854 * * *$ \\
\hline M1 & $-1.750 * * *$ & $-0.925^{* * *}$ \\
\hline M2 & $-1.660^{* * *}$ & $-0.896^{* * *}$ \\
\hline \multicolumn{3}{|l|}{ Panel B: Corruption } \\
\hline Baseline & $0.375^{* * *}$ & $0.299 * * *$ \\
\hline M1 & $0.328^{* * *}$ & $0.275^{* * *}$ \\
\hline M2 & $0.316^{* * *}$ & $0.250^{* * *}$ \\
\hline \multicolumn{3}{|l|}{ Panel C: Rule of Law } \\
\hline Baseline & $-0.239 * * *$ & $-0.196 * * *$ \\
\hline M1 & $-0.096^{* * *}$ & $-0.170^{* * *}$ \\
\hline M2 & $-0.115^{* * *}$ & $-0.144^{* * *}$ \\
\hline
\end{tabular}

\subsection{Robustness}

We tested the robustness of our results vis-à-vis several potential threats to the validity of our estimates. First, over this long historical period considered, many of the countries underwent specific shocks in different time periods. For instance, former colonies in Asia and Africa achieved independence from their European colonial rulers at different points in time over a quite long period, spanning from 1945 to 1980. Hence, we re-estimated the model adding interaction terms of country and decade dummies, which account for specific shocks experienced by each country. The results of this exercise, reported in Tables B3-B5 in Appendix B, confirm our main findings, although the magnitude of our main coefficients of interest is substantially reduced, pointing to the importance of these events in shaping practices of corruption and the provision of public goods.

Second, as clientelistic practices are repeated transactions, and as corruption, rule of law, and laws regulating public goods provision tend to evolve slowly over time, the effect of political clientelism on the dependent variables may be felt over a longer time horizon. Moreover, time-variant unobserved confounders or co-integrated trends can generate a spurious relationship between political clientelism and our dependent variables. For these reasons, we complement our main results by providing additional estimates of the coefficients of our key independent variables. These are obtained by reshaping our data set to get ten-year averages of all the variables and applying the subsystem limited information 
maximum-likelihood (ss-LIML) estimator, which is asymptotically equivalent to the standard panel generalized method of moment as $\mathrm{N} \rightarrow \infty$ for fixed $\mathrm{T}$, but tends to present smaller biases in finite samples (Moral-Benito 2013; Moral-Benito et al. 2019). ${ }^{9}$ The results are reported in Tables B6 and B7 in Appendix B. As can be observed, the time horizon on which these estimates are based starts in 1960, once the relevant variables for most of the SubSaharan African countries start to be coded. ${ }^{10} \mathrm{~A}$ strongly balanced panel data set and a small $\mathrm{T}$ (less than ten) is indeed a key requirement for the estimation of the ss-LIML model.

Once accounting for persistence and mean-reverting dynamics of the dependent variable, while statistical significance is preserved in most of the specifications, the magnitude of the coefficients is smaller compared to our OLS panel fixed effects regressions. Confirming the results of our benchmark OLS regressions, political patronage seems moreover to exert, with respect to vote buying, a relatively larger impact in driving the relationship between clientelism and the two governance measures. On the other hand, the estimation with the ss-LIML model shows a relatively small and not statistically significant influence of vote-buying practices on the universalism of public programmes.

A third issue pertains to the potential coder-induced bias. Our core results could indeed be upward biased since some V-Dem coders are rating multiple V-Dem surveys and thus scoring countries on both of the indicators included in the left- and right-hand side variables. If some proportion of coders rate variables on both sides to reflect an underlying latent dimension, this would result in a spurious, upward bias. This issue has been investigated, however, with a focus on closely related variables measuring corruption and democracy, for example, including rerunning all results with all coders rating variables on both sides of the equation removed and finding no evidence of such bias (McMann et al. 2020, 2021). In addition, several studies have indicated the robustness of the V-Dem ratings to coder biases and mistakes (e.g., Marquardt 2020; Marquardt et al. 2019).

To test the robustness of our results against the potential threat of coder-induced bias, we replicate our analysis by replacing our core dependent variables with alternative proxies available from other sources. Tables B8 and B9 in Appendix B report the results obtained using the Welfare State Encompassingness and Universalism Index from the Social Policy

\footnotetext{
${ }^{9}$ Standard GMM techniques have indeed been questioned in the literature because of their considerable smallsample bias, especially when the instruments are weak and the number of moment conditions is large relative to the cross-section dimension. In the late 1990s, alternative estimators such as LIML (Alonso-Borrego and Arellano 1999), system GMM (Blundell and Bond 1998), and maximum-likelihood estimators (Hsiao et al. 2002) have been proposed to address this limit of the standard GMM estimator. In this paper we rely on the state of the art of the econometric literature in this field and adopt the ss-LIML estimator, which-as shown by Moral-Benito (2013) — results in smaller biases compared to the aforementioned competing estimators.

${ }^{10}$ Each $\mathrm{T}$ in our ss-LIML specifications represents a period of ten years.
} 
around the World (SPaW) database as proxies for public good provision. ${ }^{11}$ Encompassingness is measured as the number of major, national welfare laws for each of the following six policy areas: old age, unemployment, maternity leave, childbirth (family allowances), work injury, and sickness. It thus ranges from 0 (no major programme) to 6 (major programmes in all areas). ${ }^{12}$

The SPaW Universalism Index is represented by the number of social groups covered for the same six major policy areas as for Encompassingness. ${ }^{13}$ Our results confirm our main findings even if the substantive effect is relatively small. Overall, the more political clientelism is widespread in a country, the less encompassing tends to be the welfare state. A one-unit difference in the political clientelism index is related to a decrease in the number of major national welfare programmes by about $0.20-0.25$. This magnitude is statistically significant but substantively very small as it corresponds to about 5-7 per cent of the sample mean number of programmes (3.5). Country-year observations with higher levels of political clientelism are associated moreover with lower beneficiaries' coverage in welfare programmes. Nevertheless, in this latter case, the statistical significance of the main coefficient is not preserved once controlling for democracy and other country-specific characteristics.

Lastly, we restrict our panel to a shorter time series (starting from 1950, 1970, or 1985, depending on the dependent variable used) and use government expenditure in education, the share of government consumption, and the ICRG Indicator of Government Quality as three additional proxies for public good provision and governance. ${ }^{14}$ Our results, reported in Tables B10-B12 in Appendix B, provide evidence that clientelistic countries exhibit, compared to the non-clientelistic ones, significantly lower levels of public spending, smaller GDP shares of expenditure on education, and worse levels of government quality.

\footnotetext{
11 The SPaW database (Rasmussen 2016; Rasmussen and Knutsen 2019) is a unique compilation of social policies around the world from 1871 to 2013. For each country-year, major welfare state law for several policies is coded across three main dimensions: whether claimants are granted benefits by necessity and need, by citizenship, and by socioeconomic group. Moreover, detailed information is provided on the generosity of enacted welfare programmes.

${ }^{12}$ It is to be noted that for a national welfare law to be considered, it has to be 'major' - that is, at least one of the following eight social groups are covered by the law: agricultural workers, industrial or production workers, small-firm workers, selfemployed, students, employers, temporary or casual workers, and family/domestic workers (Knutsen and Rasmussen 2018).

13 Programmes that automatically include all citizens are scored 9. Hence, the indicator ranges from 0 , for no major programme in any of the areas, to 54, for all citizens are covered in each of the six areas (Knutsen and Rasmussen 2018).

14 The IRCG Indicator of Government Quality, available in the Quality of Government (QOG) database (Dahlberg et al. 2019) is constructed as the mean value of the ICRG variables 'Corruption', 'Law and Order', and 'Bureaucracy Quality', scaled 0-1. Higher values indicate higher quality of government.
} 


\section{Concluding remarks}

It is widely believed that political clientelism has adverse development outcomes—as Stokes (2011: 1) notes, 'if most scholars are right, political clientelism slows economic development, vitiates democracy, and allows dictators to hold on to power longer than they otherwise would'. In this paper, we examine the effects of political clientelism on two specific development outcomes: the provision of public goods and the quality of governance. Using a panel of 161 countries over the period 1900-2017, we find negative effects of political clientelism on development outcomes, with increases in clientelism leading to lower public goods provision, increased political corruption, and weaker rule of law.

In terms of public goods provision outcomes, political clientelism tends to reduce the universality of public programmes, but to a limited extent. We also find that the deleterious effects of political clientelism are mainly through non-programmatic party linkages rather than the practice of vote buying. Our results are robust to alternate measures of public goods provision and different empirical specifications. A defining feature of economic and political development is the move from personalized to impersonal systems of governance (North et al. 2009), which is closely linked to a shift away from non-programmatic to programmatic modes of distribution. While there may be static redistributive benefits of political clientelism if particularistic benefits go mostly to the poor, this paper shows that it has long-run negative effects on the development of the welfare state, and on governance quality. While economic development itself may contribute to the decline of political clientelism, our findings suggest that in regions of the world where clientelistic politics remains prevalent (as in MENA, SubSaharan Africa, and South Asia), supply-side interventions such as programmatic social welfare programmes and media campaigns against vote buying may be needed to bring about an erosion of political clientelism.

\section{References}

Alonso-Borrego, C., and M. Arellano (1999). 'Symmetrically Normalized Instrumental Variable Estimation Using Panel Data'. Journal of Business and Economic Statistic, 17: 36-49. https://doi.org/10.1080/07350015.1999. 10524795

Auyero, J. (2000). 'The Logic of Clientelism in Argentina: An Ethnographic Account'. Latin American Research Review, 35(3): 55-81.

Barbieri, K., O.M.G. Keshk, and B. Pollins (2009). 'Trading Data: Evaluating our Assumptions and Coding Rules'. Conflict Management and Peace Science, 26(5): 471-91. https:/ / doi.org/10.1177/0738894209343887

Bardhan, P. (2021). 'Clientelism and Governance'. WIDER Working Paper. Helsinki: UNU-WIDER. 
Bardhan, P., and D. Mookherjee (2006). 'Pro-Poor Targeting and Accountability of Local Governments in West Bengal'. Journal of Development Economics, 79(2), 303-27. https://doi.org/10.1016/j.jdeveco.2006. 01.004

Bardhan, P., and D. Mookherjee (2020). 'Clientelistic Politics and Economic Development: An Overview'. In F. Buorguignon, J.-P. Platteau, J.M. Baland, and T. Verdier, The Handbook of Economic Development and Institutions. Princeton, NJ: Princeton University Press. https://doi.org/10.2307/j.ctvm7bbxr.6

Blundell, R., and S. Bond (1998). 'Initial Conditions and Moment Restrictions in Dynamic Panel Data Models'. Journal of Econometrics, 87: 115-43. https://doi.org/10.1016/S0304-4076(98)00009-8

Bolt, J., R. Inklaar, H. de Jong, and J. Luiten van Zanden (2018). 'Rebasing "Maddison": New Income Comparisons and the Shape of Long-Run Economic Development'. Maddison Project Working paper 10. Groningen: University of Groningen.

Bueno de Mesquita, B. (2003). The Logic of Political Survival. Cambridge, MA: MIT Press. https://doi.org/10. 7551/mitpress/4292.001.0001

Clio-Infra (2018). Clio-Infra Project. Database. Available at: www.clio-infra.eu.

Coppedge, M., J. Gerring, C.H. Knutsen, S.I. Lindberg, J. Teorell, D. Altman, M. Bernhard, M.S. Fish, A. Glynn, A. Hicken, A. Lührmann, K.L. Marquardt, K. McMann, P. Paxton, D. Pemstein, B. Seim, R. Sigman, S.E. Skaaning, J. Staton, A. Cornell, L. Gastaldi, H. Gjerløw, V. Mechkova, J. von Römer, A. Sundtröm, E. Tzelgov, L. Uberti, Y.T. Wang, T. Wig, and D. Ziblatt (2019a) V-Dem Codebook v9. Varieties of Democracy (V-Dem) Project. Gothenburg: Varieties of Democracy Institute. https://doi.org/10.2139/ssrn.3441060

Coppedge, M., J. Gerring, C.H. Knutsen, S.I. Lindberg, J. Teorell, D. Altman, M. Bernhard, M.S. Fish, A. Glynn, A. Hicken, A. Lührmann, K.L. Marquardt, K. McMann, P. Paxton, D. Pemstein, B. Seim, R. Sigman, S.E. Skaaning, J. Staton, S. Wilson, A. Cornell, L. Gastaldi, H. Gjerløw, N. Ilchenko, J. Krusell, L. Maxwell, V. Mechkova, J. Medzihorsky, J. Pernes, J. von Römer, N. Stepanova, A. Sundström, E. Tzelgov, Y.T.

Wang, T. Wig, and D. Ziblatt (2019b). 'V-Dem [Country-Year/Country-Date] Dataset v9'. Varieties of Democracy (V-Dem) Project. Gothenburg: Varieties of Democracy Institute. https://doi.org/10.2139/ssrn.3441052

Dahlberg, S., S. Holmberg, B. Rothstein, N. Alvarado Pachon, and R. Svensson (2019). 'The Quality of Government Basic Dataset'. Version Jan19. Gothenburg: University of Gothenburg, the Quality of Government Institute.

Deacon, R.T. (2009) 'Public Good Provision Under Dictatorship and Democracy'. Public Choice, 139 (1-2): 241-62. https:// doi.org/10.1007/s11127-008-9391-x

Didenko, D., P. Földvári, and B. van Leeuwen (2012), 'A Dataset on Human Capital in the Former Soviet Union Area: Sources, Methods, and First Results’. Working Paper 0035. Utrecht: Utrecht University.

Dixit, A., and J. Londregan (1996). 'The Determinants of Success of Special Interests in Redistributive Politics'. Journal of Politics, 58: 1132-55. https://doi.org/10.2307/2960152

Edgell, A.B., M.C. Wilson, V.A. Boese, and S. Grahn (2020). 'Democratic Legacies: Using Democratic Stock to Assess Norms, Growth and Regime Trajectories'. Working Paper 100. Gothenburg: Varieties of Democracy Institute. https:// doi.org/10.2139/ssrn.3595957

Feenstra, R.C., R. Inklaar, and M.P. Timmer (2015). 'The Next Generation of the Penn World Table'. American Economic Review, 105(10): 3150-82. https://doi.org/10.1257/aer.20130954 
Földvári, P., and B. van Leeuwen (2014). 'Educational and Income Inequality in Europe, ca. 1870-2000'. Cliometrica, 8(3): 271-300. https://doi.org/10.1007/s11698-013-0105-3

Gerring, J., S.C. Thacker, and R. Alfaro (2012). 'Democracy and Human Development'. Journal of Politics, 74(1): 1-17. https://doi.org/10.1017/S0022381611001113

Goldewijk, K., A. Beusen, and P. Janssen (2010). 'Long-Term Dynamic Modeling of Global Population and Built-Up Area in a Spatially Explicit Way: HYDE 3.1'. Holocene, 20(4): 565-73. https://doi.org/10.1177/0959683609356587

Gouldner, A.W. (1960). 'The Norm of Reciprocity: A Preliminary Statement'. American Sociological Review, 25(2): 161-78. https://doi.org/10.2307/2092623

Haber, S., and V. Menaldo (2011). 'Do Natural Resources Fuel Authoritarianism? A Reappraisal of the Resource Curse'. American Political Science Review, 105(1): 1-26. https://doi.org/10.1017/S0003055410000584

Hicken, A. (2011). 'Clientelism'. Annual Review of Political Science, 14: 289-310. https://doi.org/10.1146/ annurev.polisci.031908.220508

Holland, A. (2016). 'Forbearance'. American Political Science Review, 110(2): 232-46. https:// doi.org/10.1017/ S0003055416000083

Holland, A. (2017). Forbearance as Distribution: The Politics of Informal Welfare in Latin America. Cambridge: Cambridge University Press. https://doi.org/10.1017/9781316795613

Hsiao, C., H. Pesaran, and A. Tahmiscioglu (2002). 'Maximum Likelihood Estimation of Fixed Effects Dynamic Panel Data Models Covering Short Time Periods'. Journal of Econometrics, 109: 107-50. https://doi.org/10. 1016/S0304-4076(01)00143-9

Human Life-Table Database (2007). 'The Human Life Table Database'. Available at: www.lifetable.de/cgibin/ index.php.

Human Mortality Database (2008). 'The Human Mortality Database'. Available at: www.mortality.orgwww. humanmortality.de.

Johnston, M. (1979). 'Patrons and Clients, Jobs and Machines: A Case Study of the Uses of Patronage'. American Political Science Review, 73(2): 385-98. https://doi.org/10.2307/1954886

Kaufman, R. (1974). 'The Patron-Client Concept and Macro-Politics: Prospects and Problems'. Comparative Studies in Society and History, 16(3): 284-308. https://doi.org/10.1017/S0010417500012457

Keefer, P. (2007). 'Clientelism, Credibility, and the Policy Choices of Young Democracies'. American Journal of Political Science, 51(4): 804-21. https://doi.org/10.1111/j.1540-5907.2007.00282.x

Keefer, P., and R. Vlaicu (2008). 'Democracy, Credibility and Clientelism'. Journal of Law, Economics and Organization, 24(2): 371-406. https://doi.org/10.1093/jleo/ewm054

Kitschelt, H., and S.I. Wilkinson (2007). 'Citizen-Politician Linkages: An Introduction'. In H. Kitschelt and S.I. Wilkinson (eds), Patrons, Clients, and Policies. Cambridge: Cambridge University Press.

Knutsen, C.H., and M.B. Rasmussen (2018). 'The Autocratic Welfare State Resource Distribution, Credible Commitments and Political Survival'. Comparative Political Studies, 51(5): 659-95. https://doi.org/10.1177/ 0010414017710265 
Lake, D.A., and M.A. Baum (2001). 'The Invisible Hand of Democracy: Political Control and the Provision of Public Services'. Comparative Political Studies, 34(6): 587-621. https://doi.org/10.1177/0010414001034006001

Landé, C.H. (1977). 'Introduction: the Dyadic Basis of Clientelism'. In S.W. Schmidt, J.C. Scott, C. Landé, and L. Guasti (eds), Friends, Followers, and Factions: A Reader in Political Clientelism. Berkeley, CA: University of California Press.

Landé, C. (1983). 'Political Clientelism in Political Studies: Retrospect and Prospects'. International Political Science Review/Revue Internationale De Science Politique, 4(4): 435-54.

https://doi.org/10.1177/019251218300400403

Lemarchand, R. (1972). 'Political Clientelism and Ethnicity in Tropical Africa: Competing Solidarities in Nation Building'. American Political Science Review 66(1): 68-90. https:/ / doi.org/10.2307/1959279

Lemarchand, R., and K. Legg (1972). 'Political Clientelism and Development: A Preliminary Analysis'. Comparative Politics, 4(2): 149-78. https://doi.org/10.2307/421508

Lindberg, S.I. (2003). 'It's Our Time to "Chop": Do Elections in Africa Feed Neopatrimonialism rather than Counter-Act It?'. Democratization, 14(2): 121-40. https:// doi.org/10.1080/714000118

Lindberg, S.I. (2010). 'What Accountability Pressures Do MPs in Africa Face and How Do They Respond? Evidence from Ghana'. Journal of Modern African Studies 48(1): 117-42. https://doi.org/10.1017/S0022278X09990243

Lizzeri, A., and N. Persico (2004). 'Why Did the Elites Extend the Suffrage?'. Quarterly Journal of Economics, 119(2): 707-65. https:// doi.org/10.1162/0033553041382175

Lust-Okar, E. (2009). 'Legislative Elections in Hegemonic Authoritarian Regimes: Competitive Clientelism and Resistance to Democratization'. In S.I. Lindberg (ed.), Democratization by Elections: A New Mode of Transition. Baltimore, MD: Johns Hopkins University Press.

Markussen, T. (2011). 'Inequality and Political Clientelism: Evidence from South India'. Journal of Development Studies, 47(11): 1721-38. https:// doi.org/10.1080/00220388.2011.561330

Marquardt, K.L. (2020). 'How and How Much Does Expert Error Matter? Implications for Quantitative Peace Research'. Journal of Peace Research, 57(6): 692-700. https:/ / doi.org/10.1177/0022343320959121

Marquardt, K.L., D. Pemstein, B. Seim, and Y.T. Wang. (2019). 'What Makes Experts Reliable? Expert Reliability and the Estimation of Latent Traits'. Research \& Politics, 6(4): 2053168019879561. https://doi.org/10.1177/ 2053168019879561

McGuire, J.W. (2010). Wealth, Health, and Democracy in East Asia and Latin America. Cambridge: Cambridge University Press. https://doi.org/10.1017/CBO9780511750656

McMann, K., B. Seim, J. Teorell, and S. I. Lindberg. (2020). 'Why Low Levels of Democracy Promote Corruption and High Levels Diminish It'. Political Research Quarterly, 73(4): 893-907. https://doi.org/10.1177/ 1065912919862054

McMann, K., D. Pemstein, B. Seim, J. Teorell, and S.I. Lindberg. (2021). 'Strategies of Validation: Assessing the Varieties of Democracy Corruption Data'. Political Analysis, forthcoming.

Min, B. (2015). Power and the Vote: Elections and Electricity in the Developing World. Cambridge: Cambridge University Press. https://doi.org/10.1017/CBO9781316272121

Mitchell, B. (1998a). International Historical Statistics: Africa, Asia and Oceania, 1750-1993, 3rd edition. Basingstoke: Macmillan. 
Mitchell, B. (1998b). International Historical Statistics: Europe, 1750-1993, 4th edition. Basingstoke: Macmillan.

Mitchell, B. (1998c). International Historical Statistics: The Americas 1750-1993, 4th edition. Basingstoke: Macmillan.

Moral-Benito, E. (2013). 'Likelihood-Based Estimation of Dynamic Panels with Predetermined Regressors'. Journal of Business and Economic Statistics, 31(4): 451-72. https:// doi.org/10.1080/07350015.2013.818003

Moral-Benito, E., P. Allison, and R. Williams (2019).'Dynamic Panel Data Modelling Using Maximum Likelihood: An Alternative to Arellano-Bond'. Applied Economics, 51(20): 2221-32. https://doi.org/10.1080/ 00036846.2018.1540854

Nathan, N.L. (2019). Electoral Politics and Africa's Urban Transition: Class and Ethnicity in Ghana. Cambridge: Cambridge University Press. https://doi.org/10.1017/9781108594820

North, D.C., B. Weingast, and J. Wallis (2009). Violence and Social Orders: A Conceptual Framework for Interpreting Recording Human History. Cambridge: Cambridge University Press. https://doi.org/10.1017/ CBO9780511575839

Pemstein, D., K.L Marquardt, E. Tzelgov, Y.T. Wang, J. Medzihorsky, J. Krusell, F. Miri, and J. von Römer (2019). 'The V-Dem Measurement Model: Latent Variable Analysis for Cross-National and CrossTemporal Expert-Coded Data'. V-Dem Working Paper 21, 4th edition. Gothenburg: Varieties of Democracy Institute. https://doi.org/10.2139/ssm.3167764

Powell, J.D. (1970). 'Peasant Society and Clientelist Politics'. American Political Science Review, 64(2): 411-25. https://doi.org/10.2307/1953841

Rasmussen, M.B. (2016). The Social Policy around the World (SPaW) Database: Codebook. Available at: www. researchgate.net/publication/299445433 (accessed 28 May 2021).

Rasmussen, M.B., and C.H. Knutsen (2019). Replication Data for: Party Institutionalization and Welfare State Development. Harvard Dataverse, V1. https://doi.org/10.7910/DVN/EDHLIN.

Riley, J.C. (2005a).'Estimates of Regional and Global Life Expectancy, 1800-2001'. Population and Development Review, 31(3): 537-43. https:// doi.org/10.1111/j.1728-4457.2005.00083.x

Riley, J.C. (2005b). 'The Timing and Pace of Health Transitions Around the World'. Population and Development Review, 31(4): 741-64. https:// doi.org/10.1111/j.1728-4457.2005.00096.x

Robinson, J.A., and T. Verdier (2013). 'The Political Economy of Clientelism'. Scandinavian Joumal of Economics, 115(2): 260-91. https://doi.org/10.1111/sjoe.12010

Schmidt, S.W., J.C. Scott, C. Lande, and L. Guasti (1977). Friends, Followers, and Factions: A Reader in Political Clientelism. Berkeley, CA: University of California Press.

Scott, J.C. (1969). 'Corruption, Machine Politics, and Political Change'. American Political Science Review, 63(4): 1142-58. https://doi.org/10.2307/1955076

Scott, J.C. (1972). 'Patron-Client Politics and Political Change in Southeast Asia'. American Political Science Review, 66: 91-113. https:// doi.org/10.2307/1959280

Singer, M. (2009). 'Buying Voters with Dirty Money: The Relationship between Clientelism and Corruption’. APSA 2009 Toronto Meeting Paper. Available at: https://ssrn.com/abstract=1449001. 
Stokes, S.C. (2005). 'Perverse Accountability: A Formal Model of Machine Politics with Evidence from Argentina'. American Political Science Review, 99: 315-25. https://doi.org/10.1017/S0003055405051683

Stokes, S.C. (2011). 'Political Clientelism'. In C. Boix and S. C. Stokes (eds), The Oxford Handbook of Comparative Politics. Oxford: Oxford University Press. https://doi.org/10.1093/oxfordhb/9780199604456.013. 0031

Stokes, S.C., T. Dunning, M. Nazareno, and V. Brusco (2013). Brokers, Voters, and Clientelism: The Puzzle of Distributive Politics. Cambridge: Cambridge University Press. https://doi.org/10.1017/CBO9781107324909

Teorell, J., M. Coppedge, S.I. Lindberg, and S.E. Skaaning (2019).'Measuring Polyarchy Across the Globe, 1900-2017'. Studies in Comparative International Development, 54(1): 71-95. https://doi.org/10.1007/ s12116018-9268-z

UNESCO (n.d.). Statistical Yearbook (1963-1999). Paris: UNESCO.

United Nations Population Division (2010).World Population Prospects: The 2008 Revision. Life Expectancy at Birth, Both Sexes, Estimates 1950-2009. New York: United Nations.

van Leeuwen, B., J. van Leeuwen-Li, and P. Földvári (2011). 'Regional Human Capital in Republican and New China: Its Spread, Quality and Effects on Economic Growth’. MPRA Working Paper 43582. Munich: University Library of Munich.

van Leeuwen, B., J. van Leeuwen-Li, and P. Földvári (2012). 'Education as a Driver of Income Inequality in Twentieth-Century Africa'. MPRA Working Paper 43574. Munich: University Library of Munich.

Vanhanen, T. (1997). Prospects of Democracy: A Study of 172 Countries. London: Routledge.

Wolfinger, R.E. (1972). 'Why Machine Politics Has Not Withered Away, and Other Revisionist Thoughts'. Journal of Politics, 74(4): 1153-70.

World Bank (2019). World Development Indicators 2019. Washington, DC: World Bank. 


\section{Appendix}

\section{Appendix A: Definition of variables}

Political clientelism index.

To what extent are politics based on clientelistic relationships? Clientelistic relationships include the targeted, contingent distribution of resources (goods, services, jobs, money, etc.) in exchange for political support. The index is formed by taking the reversed point estimates (so that higher scores mean more clientelism) from a Bayesian factor analysis model of the indicators for vote buying (v2elvotbuy) and whether party linkages are programmatic or clientelistic (v2psprlnks). Since v2elvotbuy is only measured in the years in which elections take place, we impute using the most recent known value. For years before an election ever took place (meaning there is no most recent known value) we impute up to ten previous years using the value of v2elvotbuy in the first election conducted. Source: authors' computation based on the V-Dem data set (Coppedge et al. 2019a).

\section{Party linkages (v2psprlnks-osp).}

Linearized original scale posterior prediction of the ordinal variable 'party linkages'. The original ordinal variable is based on the following question: 'Among the major parties, what is the main or most common form of linkage to their constituents? A party-constituent linkage refers to the sort of "good" that the party offers in exchange for political support and participation in party activities. Responses: (0) Clientelistic. Constituents are rewarded with goods, cash, and/or jobs. (1) Mixed clientelistic and local collective. (2) Local collective. Constituents are rewarded with local collective goods, e.g., wells, toilets, markets, roads, bridges, and local development. (3) Mixed local collective and policy/programmatic. (4) Policy/programmatic. Constituents respond to a party's positions on national policies, general party programs, and visions for society.' Source: V-Dem data set (Coppedge et al. 2019a, 2019b).

\section{Election vote buying (v2elvotbuy-osp).}

Linearized original scale posterior prediction of the ordinal variable 'vote buying'. The original ordinal variable is based on the following question: 'In this national election, was there evidence of vote and/or turnout buying? Vote and turnout buying refers to the distribution of money or gifts to individuals, families, or small groups in order to influence their decision to vote/not vote or whom to vote for. It does not include legislation targeted at specific constituencies, i.e., "porkbarrel" legislation. 0: Yes. There was systematic, 
widespread, and almost nationwide vote/turnout buying by almost all parties and candidates. 1: Yes, some. There were non-systematic but rather common vote-buying efforts, even if only in some parts of the country or by one or a few parties. 2: Restricted. Money and/or personal gifts were distributed by parties or candidates, but these offerings were more about meeting an "entry-ticket" expectation and less about actual vote choice or turnout, even if a smaller number of individuals may also be persuaded. 3: Almost none. There was limited use of money and personal gifts, or these attempts were limited to a few small areas of the country. In all, they probably affected less than a few percent of voters. 4: None. There was no evidence of vote/turnout buying. Scale: Ordinal, converted to interval by the measurement model.' Source: V-Dem data set (Coppedge et al. 2019a, 2019b).

\section{Universal welfare programmes indicator (v2dlunivl-osp).}

Linearized original scale posterior prediction of the ordinal variable 'Means-tested v. universalistic policy'. The original ordinal variable is based on the following question: 'How many welfare programs are means-tested and how many benefit all (or virtually all) members of the polity? A means-tested program targets poor, needy, or otherwise underprivileged constituents. Cash-transfer programs are normally means-tested. A universal (nonmeans tested) program potentially benefits everyone. This includes free education, national health care schemes, and retirement programs. Granted, some may benefit more than others from these programs (e.g., when people with higher salaries get higher unemployment benefits). The key point is that practically everyone is a beneficiary, or potential beneficiary. The purpose of this question is not to gauge the size of the welfare state but rather its quality. Responses: (0) There are no, or extremely limited, welfare state policies (education, health, retirement, unemployment, poverty programs). (1) Almost all of the welfare state policies are means-tested. (2) Most welfare state policies means-tested, but a significant portion (e.g. 1/4 or 1/3) is universalistic and potentially benefits everyone in the population. (3) The welfare state policies are roughly evenly divided between means-tested and universalistic. (4) Most welfare state policies are universalistic, but a significant portion (e.g., 1/4 or 1/3) are meanstested. (5) Almost all welfare state policies are universal in character. Only a small portion is means-tested.' Source: V-Dem data set (Coppedge et al. 2019a, 2019b).

\section{Political corruption index $(v 2 x-$ corr $)$.}

The directionality of the V-Dem corruption index runs from less corrupt to more corrupt. The index is arrived at by taking the average of (a) the public sector corruption index $(v 2 x-p u b c o r r) ;(b)$ the executive corruption index $(v 2 x-$ execorr $)$; (c) the indicator for legislative 
corruption $(v 2 \lg c r p t)$; and $(\mathrm{d})$ the indicator for judicial corruption $(v 2 j u c o r r d c)$.These four different government spheres are weighted equally in the resulting index. Missing values for countries with no legislature are replaced by only taking the average of a, b, and d. Source: V-Dem data set (Coppedge et al. 2019a, 2019b).

Rule of law index $(v 2 x-$ rule).

To what extent are laws transparently, independently, predictably, impartially, and equally enforced, and to what extent do the actions of government officials comply with the law? The index is formed by taking the point estimates from a Bayesian factor analysis model of the indicators for compliance with high courts (v2juhccomp), compliance with the judiciary (v2jucomp), high court independence (v2jubcind), lower court independence (v2juncind), the executive respects the constitution (v2exrescon), rigorous and impartial public administration $(v 2 c l r s p c t)$, transparent laws with predictable enforcement $(v 2 c l t r n s h)$, access to justice for men $(v 2$ clacjstm), access to justice for women ( $v 2$ clacjstw $)$, judicial accountability ( $22 j u a c c n t)$, judicial corruption decisions ( $v 2 j u c o r r d c)$, public sector corrupt exchanges (v2excrptps), public sector theft (v2exthftps), executive bribery and corrupt exchanges (v2exbribe), and executive embezzlement and theft (v2exember). Source: V-Dem data set (Coppedge et al. 2019a, 2019b).

\section{Electoral democracy index $(v 2 x-$ polyarchy).}

The democracy index from V-dem, capturing 'electoral democracy' - that is, the core value of making rulers responsive to citizens, achieved through electoral competition for the electorate's approval under circumstances when suffrage is extensive; political and civil society organizations can operate freely; elections are clean and not marred by fraud or systematic irregularities; and elections affect the composition of the chief executive of the country. In between elections, there is freedom of expression and an independent media capable of presenting alternative views on matters of political relevance. The index is formed by taking the average of, on the one hand, the weighted average of the indices measuring freedom of association thick ( $v 2 x-$ frassoc-thick), clean elections ( $v 2 x e l-f r e f a i r)$, freedom of expression $(v 2 x-$ freexp-altinf $)$, elected officials $(v 2 x-$ elecof $f)$, and suffrage $(v 2 x-s u f f r)$ and, on the other, the five-way multiplicative interaction between those indices. Source: V-Dem data set (Coppedge et al. 2019a, 2019b).

\section{Stock of democracy.}

This variable is computed as the sum of the value of electoral democracy at time $t$ and at time $t-1$, minus 10 per cent of depreciation at time $t-1$. Source: authors' computation based on the V-Dem data set (Coppedge et al. 2019a, 2019b). 
Encompassingness. The number of major national welfare programmes within six risk areas that are enacted. For a programme to count as 'major', at least one out of a predefined set of relatively broad social groups needs to be covered. The relevant groups are: agricultural workers; industrial/production workers; small-firm workers; self-employed; students; employers; temporary/casual workers; and family/domestic workers. Source: Social Policy around the World (SPaW) database (Rasmussen 2016), retrieved from Rasmussen and Knutsen (2019).

\section{Universalism index.}

An additive index, aggregating across programmes for six major areas of risk covered in $\mathrm{SPaW}$. Each area is scored 0 if there is no programme; 1 if a programme is means-tested according to some property criterion (income-based exclusions are not considered meanstested); 2 if one social group is covered by a contribution- or employment-based programme; 3 if two groups are covered, etc. The social groups counted are agricultural workers; industrial/production workers; small-firm workers; self-employed; students; employers; temporary/casual workers; and family/domestic workers. If the programme automatically includes all citizens, 9 is given. Source: SPaW database (Rasmussen 2016), retrieved from Rasmussen and Knutsen (2019).

\section{Government consumption.}

Share of government consumption at current purchasing power parity (PPP). Source: PWT 9.0 (Feenstra et al. 2015).

\section{Government expenditure on education.}

General government expenditure on education (current, capital, and transfers) is expressed as a percentage of GDP. This includes expenditure funded by transfers from international sources to government. General government usually refers to local, regional, and central governments. Source: World Development Indicators (World Bank 2019), retrieved from the V-Dem database (Coppedge et al. 2019a).

\section{ICRG Indicator of Government Quality.}

The mean value of the ICRG variables 'Corruption', 'Law and Order', and 'Bureaucracy Quality', scaled 0-1. Higher values indicate higher quality of government. Source: Dahlberg et al. (2019).

\section{Ln population.}


The population count, log-transformed. Source: Clio Infra (2018), drawing on Goldewijk et al. (2010), History Database of Global Environment (www.pbl.nl/hyde), retrieved from the V-Dem database (Coppedge et al. 2019a).

Ln GDP per capita.

Real, PPP-adjusted GDP per capita, log-transformed. Source: the Maddison Project Database (Bolt et al. 2018), retrieved from the V-Dem database (Coppedge et al. 2019a).

Openness. Imports and exports divided by GDP.

Source: Barbieri et al. (2009) and the Maddison Project Database (Bolt et al. 2018), retrieved from the V-Dem database (Coppedge et al. 2019a).

\section{Rural inequality.}

The percentage of (cultivated) land area composed of family farms. Source: Vanhanen (1997).

Civil war.

Was there a civil war? 1 if yes and 0 otherwise. Civil war defined as at least one intrastate war with at least 1,000 battle deaths for each country-year. Source: Haber and Menaldo (2011), retrieved from the V-Dem database (Coppedge et al. 2019a).

\section{Life expectancy.}

Life expectancy refers to expected longevity at birth based on current age-specific mortality rates. Missing data within a time-series is interpolated using linear interpolation. Source: Gapminder (gapminder.org), drawing on the Human Mortality Database (2008), Riley (2005a, 2005b), the Human Life Table Database (2007), and United Nations Population Division (2010). Clio Infra (clio-infra.eu), drawing on the Human Mortality Database (2008), the Human Life Table Database (2017), the World Bank (2019), and the Montevideo-Oxford Latin America History Economic Database (http://moxlad.fcs.edu.uy/es/basededatos.html). Retrieved from the V-Dem database (Coppedge et al. 2019a).

\section{Education.}

Average years of education among citizens older than 15 years. Source: Clio Infra (clio-infra. eu), drawing on Mitchell (1998a, 1998b, 1998c), the US Census Bureau, UNESCO (n.d.), Földvári and van Leeuwen (2014), van Leeuwen et al. (2011, 2012), and Didenko et al. (2012). Retrieved from the V-Dem database (Coppedge et al. 2019a). 


\section{Appendix B: Additional results}

\section{Table B1: Summary statistics}

\begin{tabular}{|c|c|c|c|c|c|}
\hline Variable & Mean & Std dev. & Min. & Max. & $N$ \\
\hline Clientelism index & 0.494 & 0.263 & 0.029 & 0.969 & 13,094 \\
\hline Party linkages indicator & 2.008 & 1.136 & 0.056 & 3.971 & 13,054 \\
\hline Vote-buying indicator & 2.112 & 1.107 & 0.137 & 3.973 & 11,334 \\
\hline Universal welfare programmes indicator & 2.656 & 1.405 & 0.013 & 4.94 & 13,076 \\
\hline Political corruption index & 0.483 & 0.297 & 0.006 & 0.976 & 13,048 \\
\hline Rule of law index & 0.521 & 0.31 & 0.005 & 0.998 & 13,094 \\
\hline Electoral democracy index & 0.395 & 0.281 & 0.008 & 0.948 & 13,046 \\
\hline Ln GDP per capita & 8.439 & 1.129 & 4.898 & 12.305 & 11,047 \\
\hline Ln population & 8.788 & 1.689 & 3.73 & 14.142 & 12,836 \\
\hline Openness & 3.454 & 16.059 & 0 & 464.878 & 9,982 \\
\hline Education & 5.488 & 3.413 & 0.055 & 13.61 & 10,635 \\
\hline Life expectancy & 59.633 & 14.179 & 7.29 & 84.2 & 12,806 \\
\hline Rural inequality & 38.467 & 23.638 & 0 & 99 & 9,656 \\
\hline Civil war & 0.065 & 0.247 & 0 & 1 & 10,101 \\
\hline Encompassingness & 3.517 & 2.017 & 0 & 6 & 8,920 \\
\hline Universalism Index (SPaW) & 13.15 & 10.408 & 0 & 45 & 5,803 \\
\hline Government consumption & 0.188 & 0.1 & 0.008 & 1.774 & 8,366 \\
\hline Government expenditure on education & 4.395 & 1.896 & 0 & 44.334 & 3,439 \\
\hline IRCG Indicator of Government Quality & 0.544 & 0.222 & 0.042 & 1 & 4,514 \\
\hline
\end{tabular}

Source: authors' elaboration on various sources (see citations in Appendix A). 
Table B2: Overview on the coefficients of the political clientelism index across different types of political regimes

\begin{tabular}{lcc}
\hline & $\begin{array}{c}\text { Closed and electoral } \\
\text { autocracies }\end{array}$ & $\begin{array}{c}\text { Electoral and liberal } \\
\text { autocracies }\end{array}$ \\
\hline Panel A: Universal welfare programmes & $-1.853^{* * *}$ & -0.048 \\
Baseline & $-1.867^{* * *}$ & 0.081 \\
Adding stock of democracy & $-1.419^{* * *}$ & $-0.216^{*}$ \\
Adding controls & $0.308^{* * *}$ & $0.238^{* * *}$ \\
\hline Panel B: Corruption & $0.311^{* * *}$ & $0.204^{* * *}$ \\
Baseline & $0.230^{* * *}$ & $0.160^{* * *}$ \\
Adding stock of democracy & $-0.174^{* * *}$ & $-0.195^{* * *}$ \\
Adding controls & $-0.188^{* * *}$ & $-0.127^{* * *}$ \\
\hline Panel C: Rule of law & $-0.125^{* * *}$ & $-0.152^{* * *}$ \\
Baseline & Adding stock of democracy & \\
Adding controls &
\end{tabular}

Note: closed and electoral autocracies are countries with no multiparty elections or with de jure multiparty elections for the chief executive and the legislature, but which fail to achieve free and fair elections, or de facto multiparty, or a minimum level of Dahl's institutional prerequisites of polyarchy as measured by VDem's electoral democracy index. Electoral democracies are de facto free and fair multiparty elections and a minimum level of Dahl's institutional prerequisites for polyarchy as measured by V-Dem's electoral democracy index, but either access to justice, or transparent law enforcement, or liberal principles of respect for personal liberties, rule of law, and judicial as well as legislative constraints on the executive not satisfied. Liberal democracies are de facto free and fair multiparty elections and a minimum level of Dahl's institutional prerequisites for polyarchy as measured by V-Dem's electoral democracy index are guaranteed, as well as access to justice, transparent law enforcement, and the liberal principles of respect for personal liberties, rule of law, and judicial as well as legislative constraints on the executive satisfied. ${ }^{*} p<0.1,{ }^{* *} p<0.05,{ }^{* * *} p<$ 0.01 .

Source: authors' elaboration based on the V-Dem data set (Coppedge et al. 2019b). 
Table B3: Clientelism and universalism: model with country $\times$ decade fixed effects

\begin{tabular}{|c|c|c|c|}
\hline & (1) & (2) & (3) \\
\hline \multirow[t]{2}{*}{ Clientelism index $\mathrm{x}_{\mathrm{t}-1}$} & $-0.861 * * *$ & $-0.561 * * *$ & $-0.735^{* * *}$ \\
\hline & $(-8.097)$ & $(-5.510)$ & $(-6.493)$ \\
\hline \multirow[t]{2}{*}{ Ln population } & $0.240^{* * *}$ & $0.182^{* * *}$ & $0.221 * * *$ \\
\hline & $(4.938)$ & $(3.808)$ & (3.001) \\
\hline \multirow[t]{2}{*}{ Ln GDP per capitat-1 } & $0.055^{*}$ & $0.051^{*}$ & $0.143^{* * *}$ \\
\hline & $(1.919)$ & $(1.857)$ & $(2.897)$ \\
\hline \multirow[t]{2}{*}{ Electoral democracyt-1 } & & $-1.145^{* * *}$ & $-0.824 * * *$ \\
\hline & & $(-3.877)$ & $(-2.701)$ \\
\hline \multirow[t]{2}{*}{ Electoral democracy ${ }^{2}$} & & -0.255 & -0.059 \\
\hline & & $(-0.874)$ & $(-0.167)$ \\
\hline \multirow[t]{2}{*}{ Stock of democracy } & & $1.174^{* * *}$ & $0.859 * * *$ \\
\hline & & $(4.149)$ & $(2.827)$ \\
\hline Openness & & & $\begin{array}{c}-0.001 \\
(-1.034)\end{array}$ \\
\hline Education & & & $\begin{array}{c}-0.055^{* *} \\
(-2.160)\end{array}$ \\
\hline Life expectancy & & & $\begin{array}{c}0.016 * * * \\
(5.326)\end{array}$ \\
\hline Rural inequality & & & $\begin{array}{c}0.004^{* * *} \\
(3.218)\end{array}$ \\
\hline Civil war & & & $\begin{array}{l}-0.036 \\
(-1.030)\end{array}$ \\
\hline \multirow[t]{2}{*}{ Constant } & 0.123 & 0.196 & $-1.555^{*}$ \\
\hline & $(0.250)$ & $(0.408)$ & $(-1.903)$ \\
\hline Observations & 11,030 & 10,984 & 7,294 \\
\hline R-squared & 0.951 & 0.954 & 0.967 \\
\hline Country $\times$ decade FE & Yes & Yes & Yes \\
\hline Time period & 1901-2017 & $1901-2017$ & 1901-2006 \\
\hline
\end{tabular}

Note: OLS with panel corrected standard errors. $t$-values reported in parentheses. ${ }^{*} p<0.1, * * p<0.05, * * * p$ $<0.01$.

Source: authors' elaboration based on the V-Dem data set (Coppedge et al. 2019b). 


\begin{tabular}{|c|c|c|c|}
\hline & (1) & (2) & (3) \\
\hline \multirow[t]{2}{*}{ Clientelism index $\mathrm{t}-1$} & $0.213 * * *$ & $0.180^{* * *}$ & $0.140^{* * *}$ \\
\hline & $(11.657)$ & $(10.261)$ & $(6.359)$ \\
\hline \multirow[t]{2}{*}{ Ln population } & $0.041 * * *$ & $0.048^{* * *}$ & $0.068^{* * *}$ \\
\hline & $(5.367)$ & $(6.203)$ & $(5.280)$ \\
\hline \multirow[t]{2}{*}{ Ln GDP per capitat-1 } & $-0.027 * * *$ & $-0.025^{* * *}$ & $-0.027 * * *$ \\
\hline & $(-6.204)$ & $(-5.894)$ & $(-4.161)$ \\
\hline \multirow[t]{2}{*}{ Electoral democracyt-1 } & & $0.143^{* * *}$ & $0.139 * * *$ \\
\hline & & $(3.402)$ & (2.914) \\
\hline \multirow[t]{2}{*}{ Electoral democracy ${ }^{2}$} & & -0.016 & 0.017 \\
\hline & & $(-0.394)$ & $(0.375)$ \\
\hline \multirow[t]{2}{*}{ Stock of democracy } & & $-0.133^{* * *}$ & $-0.144 * * *$ \\
\hline & & $(-3.421)$ & $(-3.228)$ \\
\hline Openness & & & $\begin{array}{c}0.000 \\
(0.909)\end{array}$ \\
\hline Education & & & $\begin{array}{c}0.003 \\
(0.947)\end{array}$ \\
\hline Life expectancy & & & $\begin{array}{c}0.002 * * * \\
(3.435)\end{array}$ \\
\hline Rural inequality & & & $\begin{array}{c}0.000 \\
(1.156)\end{array}$ \\
\hline Civil war & & & $\begin{array}{l}-0.002 \\
(-0.528)\end{array}$ \\
\hline \multirow[t]{2}{*}{ Constant } & $-0.162^{* *}$ & $-0.179 * *$ & $-0.495^{* * *}$ \\
\hline & $(-2.176)$ & $(-2.399)$ & $(-3.590)$ \\
\hline Observations & 10,996 & 10,950 & 7,294 \\
\hline R-squared & 0.979 & 0.980 & 0.985 \\
\hline Country $\times$ decade FE & Yes & Yes & Yes \\
\hline Time period & 1901-2017 & 1901-2017 & 1901-2006 \\
\hline
\end{tabular}


Table B5: Clientelism and rule of law: model with country $\times$ decade fixed effects

\begin{tabular}{|c|c|c|c|}
\hline & (1) & (2) & (3) \\
\hline \multirow[t]{2}{*}{ Clientelism index $\mathrm{x}_{\mathrm{t}-1}$} & $-0.274 * * *$ & $-0.150^{* * *}$ & $-0.114 * * *$ \\
\hline & $(-14.218)$ & $(-9.872)$ & $(-6.086)$ \\
\hline \multirow[t]{2}{*}{ Ln population } & -0.008 & $-0.037 * * *$ & $-0.052^{* * *}$ \\
\hline & $(-1.024)$ & $(-5.272)$ & $(-4.523)$ \\
\hline \multirow[t]{2}{*}{ Ln GDP per capitat-1 } & $0.023 * * *$ & $0.012^{* * *}$ & $0.015^{* *}$ \\
\hline & $(4.873)$ & $(2.957)$ & $(1.978)$ \\
\hline \multirow[t]{2}{*}{ Electoral democracyt-1 } & & $-0.616^{* * *}$ & $-0.695^{* * *}$ \\
\hline & & $(-11.947)$ & $(-11.506)$ \\
\hline \multirow[t]{2}{*}{ Electoral democracy ${ }^{2}$} & & $-0.293^{* * *}$ & $-0.384 * * *$ \\
\hline & & $(-6.181)$ & $(-6.728)$ \\
\hline \multirow[t]{2}{*}{ Stock of democracy } & & $0.714^{* * *}$ & $0.804 * * *$ \\
\hline & & $(15.691)$ & $(15.105)$ \\
\hline Openness & & & $\begin{array}{l}0.000^{*} \\
(1.852)\end{array}$ \\
\hline Education & & & $\begin{array}{c}-0.010^{* * *} \\
(-3.061)\end{array}$ \\
\hline Life expectancy & & & $\begin{array}{c}-0.000 \\
(-0.783)\end{array}$ \\
\hline Rural inequality & & & $\begin{array}{c}0.000 \\
(1.385)\end{array}$ \\
\hline Civil war & & & $\begin{array}{c}0.002 \\
(0.335)\end{array}$ \\
\hline \multirow[t]{2}{*}{ Constant } & $0.926^{* * *}$ & $0.999 * * *$ & $1.187 * * *$ \\
\hline & $(12.084)$ & $(14.646)$ & (9.173) \\
\hline Observations & 11,031 & 10,985 & 7,295 \\
\hline R-squared & 0.971 & 0.981 & 0.985 \\
\hline Country $\times$ decade FE & Yes & Yes & Yes \\
\hline Time period & 1901-2017 & $1901-2017$ & 1901-2006 \\
\hline
\end{tabular}


Table B6: Dynamic panel fixed effects results using the ss-LIML estimator

\begin{tabular}{|c|c|c|c|c|c|c|}
\hline & (1) & (2) & (3) & (4) & (5) & (6) \\
\hline \multirow[t]{2}{*}{ Clientelism } & $-0.476^{* * *}$ & $-0.411 * * *$ & $0.214 * * *$ & $0.228^{* * *}$ & $-0.134 * * *$ & $-0.188^{* * *}$ \\
\hline & $(0.11)$ & $(0.04)$ & $(0.04)$ & $(0.04)$ & $(0.04)$ & $(0.03)$ \\
\hline \multirow[t]{2}{*}{ Universal welfare programmes $\mathrm{t}_{\mathrm{t}-1}$} & $0.797 * * *$ & $0.789 * * *$ & & & & \\
\hline & $(0.05)$ & $(0.12)$ & & & & \\
\hline \multirow[t]{2}{*}{ Corruption $_{\mathrm{t}-1}$} & & & $0.654 * * *$ & $0.606^{* * *}$ & & \\
\hline & & & $(0.05)$ & $(0.05)$ & & \\
\hline \multirow[t]{2}{*}{ Rule of lawt-1 } & & & & & $0.746^{* * *}$ & $0.258^{* * *}$ \\
\hline & & & & & $(0.05)$ & $(0.03)$ \\
\hline \multirow[t]{2}{*}{ Ln GDP per capitat-1 } & -0.009 & -0.004 & 0.005 & -0.001 & -0.025 & 0.014 \\
\hline & $(0.09)$ & $(0.03)$ & $(0.01)$ & $(0.01)$ & $(0.01)$ & $(0.01)$ \\
\hline \multirow[t]{2}{*}{ Ln population } & -0.016 & -0.009 & -0.016 & -0.020 & 0.018 & $-0.044^{*}$ \\
\hline & $(0.05)$ & $(0.02)$ & $(0.03)$ & $(0.03)$ & $(0.03)$ & $(0.02)$ \\
\hline \multirow[t]{2}{*}{ Electoral democracy } & & $0.073 * * *$ & & $-0.018^{* * *}$ & & $0.596^{* * *}$ \\
\hline & & $(0.01)$ & & $(0.03)$ & & $(0.03)$ \\
\hline Observations & 804 & 804 & 804 & 804 & 804 & 804 \\
\hline Countries & 134 & 134 & 134 & 134 & 134 & 134 \\
\hline Number of periods & 6 & 6 & 6 & 6 & 6 & 6 \\
\hline Time periods & $\begin{array}{c}1960- \\
2017\end{array}$ & $\begin{array}{c}1960- \\
2017\end{array}$ & $\begin{array}{c}1960- \\
2017\end{array}$ & $\begin{array}{c}1960- \\
2017\end{array}$ & $\begin{array}{c}1960- \\
2017\end{array}$ & $\begin{array}{c}1960- \\
2017\end{array}$ \\
\hline$\chi^{2}$ & 136.04 & 178.54 & 167.55 & 229.90 & 141.48 & 309.76 \\
\hline No. of over. restrictions & 59 & 78 & 59 & 78 & 59 & 78 \\
\hline$p$-value & 0.00 & 0.00 & 0.00 & 0.00 & 0.00 & 0.00 \\
\hline
\end{tabular}

Note: standard errors in parentheses. The dependent variable in specifications reported in columns 1 and 2 is universal welfare programmes; in columns 3 and 4 corruption; and in columns 5 and 6 rule of law. ${ }^{*} p<0.1$, ** $p<0.05$, *** $p<0.01$.

Source: authors' elaboration based on the V-Dem data set (Coppedge et al. 2019b). 
Table B7: Dynamic panel fixed effects results using the ss-LIML estimator: coefficients on 'party linkages' and 'vote buying'

\begin{tabular}{lcc}
\hline & Party linkages & Vote buying \\
\hline $\begin{array}{l}\text { Panel A: Universal welfare programmes } \\
\text { Baseline }\end{array}$ & $0.120^{*}$ & $0.090^{*}$ \\
M1 & $0.097^{*}$ & 0.085 \\
\hline Panel B: Corruption & $-0.059^{* * *}$ & -0.031 \\
Baseline & $-0.046^{* * *}$ & $-0.028^{* * *}$ \\
M1 & & \\
\hline Panel C: Rule of law & $0.068^{* * *}$ & $0.025^{* * *}$ \\
Baseline & $0.049^{* * *}$ & $0.040^{* * *}$ \\
M1 &
\end{tabular}

Note: $* p<0.1, * * p<0.05, * * * p<0.01$.

Source: authors' elaboration based on the V-Dem data set (Coppedge et al. 2019b). 


\begin{tabular}{|c|c|c|c|}
\hline & (1) & (2) & (3) \\
\hline \multirow[t]{2}{*}{ Clientelism index $\mathrm{t}_{\mathrm{t}-1}$} & $-0.197 * * *$ & $-0.234^{* * *}$ & $-0.248^{* * *}$ \\
\hline & $(-2.764)$ & $(-3.192)$ & $(-3.102)$ \\
\hline \multirow[t]{2}{*}{ Ln population } & $1.158^{* * *}$ & $1.067^{* * *}$ & $0.745^{* * *}$ \\
\hline & $(32.656)$ & $(27.740)$ & $(15.080)$ \\
\hline \multirow[t]{2}{*}{ Ln GDP per capitat-1 } & $0.075^{* * *}$ & $0.072^{* * *}$ & -0.042 \\
\hline & $(3.071)$ & $(2.950)$ & $(-1.302)$ \\
\hline \multirow[t]{2}{*}{ Electoral democracyt-1 } & & -0.275 & -0.615 \\
\hline & & $(-0.789)$ & $(-1.628)$ \\
\hline \multirow[t]{2}{*}{ Electoral democracy ${ }^{2}$} & & $-0.968^{* * *}$ & $-1.349 * * *$ \\
\hline & & $(-4.345)$ & $(-5.339)$ \\
\hline \multirow[t]{2}{*}{ Stock of democracy } & & $0.649 * * *$ & $0.905 * * *$ \\
\hline & & $(2.632)$ & $(3.316)$ \\
\hline Openness & & & $\begin{array}{c}0.002^{* *} \\
(2.080)\end{array}$ \\
\hline Education & & & $\begin{array}{c}0.010 \\
(0.562)\end{array}$ \\
\hline Life expectancy & & & $\begin{array}{c}0.030^{* * *} \\
(10.813)\end{array}$ \\
\hline Rural inequality & & & $\begin{array}{c}0.004 * * * \\
(4.692)\end{array}$ \\
\hline Civil war & & & $\begin{array}{c}0.027 \\
(0.646)\end{array}$ \\
\hline \multirow[t]{2}{*}{ Constant } & $-15.502^{* * *}$ & $-14.637 * * *$ & $-11.664^{* * *}$ \\
\hline & $(-28.531)$ & $(-26.424)$ & $(-17.704)$ \\
\hline Observations & 7,870 & 7,845 & 6,540 \\
\hline R-squared & 0.878 & 0.877 & 0.877 \\
\hline Number of country_id & 134 & 134 & 114 \\
\hline Country FE & Yes & Yes & Yes \\
\hline Year FE & Yes & Yes & Yes \\
\hline Time period & 1901-2013 & 1901-2013 & $1901-2006$ \\
\hline
\end{tabular}

Note: OLS with panel corrected standard errors. $t$-values reported in parentheses. ${ }^{*} p<0.1,{ }^{* *} p<0.05,{ }^{* * *} p$ $<0.01$.

Source: authors' elaboration based on the V-Dem data set (Coppedge et al. 2019b) and SPaW (Rasmussen 2016) data. 


\begin{tabular}{|c|c|c|c|}
\hline & (1) & (2) & (3) \\
\hline \multirow[t]{2}{*}{ Clientelism index $\mathrm{x}_{\mathrm{t}-1}$} & $-1.533^{* * *}$ & -0.406 & -0.719 \\
\hline & $(-3.282)$ & $(-0.875)$ & $(-1.514)$ \\
\hline \multirow[t]{2}{*}{ Ln population } & $-0.540^{*}$ & 0.146 & $-0.878^{* * *}$ \\
\hline & $(-1.913)$ & $(0.511)$ & $(-2.629)$ \\
\hline \multirow[t]{2}{*}{ Ln GDP per capitat-1 } & $1.059 * * *$ & $0.772^{* * *}$ & -0.199 \\
\hline & $(7.306)$ & $(5.239)$ & $(-1.081)$ \\
\hline \multirow[t]{2}{*}{ Electoral democracyt-1 } & & $7.596^{* * *}$ & $5.472^{* * *}$ \\
\hline & & $(4.131)$ & $(2.900)$ \\
\hline \multirow[t]{2}{*}{ Electoral democracy ${ }^{2}$} & & $7.820^{* * *}$ & $3.597 * * *$ \\
\hline & & $(6.206)$ & $(2.678)$ \\
\hline \multirow[t]{2}{*}{ Stock of democracy } & & $-5.646^{* * *}$ & $-3.038^{* *}$ \\
\hline & & $(-4.297)$ & $(-2.226)$ \\
\hline Openness & & & $\begin{array}{c}-0.051 * * * \\
(-6.261)\end{array}$ \\
\hline Education & & & $\begin{array}{c}1.224 * * * \\
(11.253)\end{array}$ \\
\hline Life expectancy & & & $\begin{array}{c}0.064^{* * *} \\
(4.020)\end{array}$ \\
\hline Rural inequality & & & $\begin{array}{c}0.032^{* * *} \\
(7.217)\end{array}$ \\
\hline Civil war & & & $\begin{array}{c}0.418^{* *} \\
(2.302)\end{array}$ \\
\hline \multirow[t]{2}{*}{ Constant } & $-14.772^{* * *}$ & $-21.158^{* * *}$ & $-14.300^{* * *}$ \\
\hline & $(-4.000)$ & $(-5.693)$ & $(-3.501)$ \\
\hline Observations & 5,014 & 4,989 & 4,351 \\
\hline R-squared & 0.909 & 0.911 & 0.911 \\
\hline Number of country_id & 126 & 126 & 108 \\
\hline Country FE & Yes & Yes & Yes \\
\hline Year FE & Yes & Yes & Yes \\
\hline Time period & 1901-2013 & 1901-2013 & 1901-2006 \\
\hline
\end{tabular}


Table B10: Clientelism and government consumption

\begin{tabular}{|c|c|c|c|}
\hline & (1) & (2) & (3) \\
\hline \multirow[t]{2}{*}{ Clientelism index $\mathrm{t}_{\mathrm{t}-1}$} & $-0.073^{* * *}$ & $-0.061 * * *$ & $-0.065^{* * *}$ \\
\hline & $(-10.153)$ & $(-7.841)$ & $(-6.690)$ \\
\hline \multirow[t]{2}{*}{ Ln population } & $-0.042^{* * *}$ & $-0.040 * * *$ & $-0.015^{* *}$ \\
\hline & $(-10.312)$ & $(-8.897)$ & $(-2.122)$ \\
\hline \multirow[t]{2}{*}{ Ln GDP per capitat-1 } & $-0.015^{* * *}$ & $-0.015^{* * *}$ & 0.003 \\
\hline & $(-4.990)$ & $(-5.119)$ & $(0.593)$ \\
\hline \multirow[t]{2}{*}{ Electoral democracyt-1 } & & 0.045 & -0.007 \\
\hline & & $(1.357)$ & $(-0.205)$ \\
\hline \multirow[t]{2}{*}{ Electoral democracy ${ }^{2}$} & & 0.036 & 0.010 \\
\hline & & (1.618) & $(0.429)$ \\
\hline \multirow[t]{2}{*}{ Stock of democracy } & & -0.023 & 0.014 \\
\hline & & $(-0.898)$ & $(0.554)$ \\
\hline Openness & & & $\begin{array}{c}0.000^{* * *} \\
(6.828)\end{array}$ \\
\hline Education & & & $\begin{array}{c}0.006 * * \\
(2.258)\end{array}$ \\
\hline Life expectancy & & & $\begin{array}{c}0.002^{* * *} \\
(4.945)\end{array}$ \\
\hline Rural inequality & & & $\begin{array}{c}-0.001 * * * \\
(-10.323)\end{array}$ \\
\hline Civil war & & & $\begin{array}{c}0.036^{* * *} \\
(8.132)\end{array}$ \\
\hline \multirow[t]{2}{*}{ Constant } & $0.733 * * *$ & $0.695^{* * *}$ & 0.126 \\
\hline & $(11.518)$ & $(10.296)$ & $(1.345)$ \\
\hline Observations & 8,103 & 8,083 & 5,139 \\
\hline R-squared & 0.547 & 0.548 & 0.662 \\
\hline Number of country_id & 155 & 155 & 121 \\
\hline Country FE & Yes & Yes & Yes \\
\hline Year FE & Yes & Yes & Yes \\
\hline Time period & 1951-2017 & 1951-2017 & 1951-2006 \\
\hline
\end{tabular}


Table B11: Clientelism and government expenditure in education

\begin{tabular}{|c|c|c|c|}
\hline & (1) & (2) & (3) \\
\hline \multirow[t]{2}{*}{ Clientelism index $\mathrm{t}_{\mathrm{t}-1}$} & $-1.472^{* * *}$ & $-1.044 * * *$ & $-0.857^{* *}$ \\
\hline & $(-4.592)$ & $(-2.989)$ & $(-2.412)$ \\
\hline \multirow[t]{2}{*}{ Ln population } & 0.056 & 0.096 & 0.156 \\
\hline & $(0.435)$ & $(0.718)$ & $(0.658)$ \\
\hline \multirow[t]{2}{*}{ Ln GDP per capitat-1 } & -0.028 & -0.012 & 0.161 \\
\hline & $(-0.192)$ & $(-0.082)$ & $(0.995)$ \\
\hline \multirow[t]{2}{*}{ Electoral democracyt-1 } & & 1.661 & 1.093 \\
\hline & & $(1.598)$ & $(0.963)$ \\
\hline \multirow[t]{2}{*}{ Electoral democracy ${ }^{2}$} & & $1.823^{* *}$ & 1.518 \\
\hline & & $(1.993)$ & $(1.538)$ \\
\hline \multirow[t]{2}{*}{ Stock of democracy } & & -1.258 & -0.923 \\
\hline & & $(-1.395)$ & $(-0.972)$ \\
\hline Openness & & & $\begin{array}{c}-0.002 \\
(-1.249)\end{array}$ \\
\hline Education & & & $\begin{array}{c}0.330^{* * *} \\
(2.657)\end{array}$ \\
\hline Life expectancy & & & $\begin{array}{c}-0.025 \\
(-1.017)\end{array}$ \\
\hline Rural inequality & & & $\begin{array}{c}-0.015^{* * *} \\
(-3.896)\end{array}$ \\
\hline Civil war & & & $\begin{array}{c}0.540^{* * *} \\
(4.546)\end{array}$ \\
\hline \multirow[t]{2}{*}{ Constant } & 3.678 & 2.312 & 1.834 \\
\hline & $(1.461)$ & $(0.949)$ & $(0.589)$ \\
\hline Observations & 3,313 & 3,313 & 1,938 \\
\hline R-squared & 0.629 & 0.632 & 0.646 \\
\hline Number of country_id & 154 & 154 & 121 \\
\hline Country FE & Yes & Yes & Yes \\
\hline Year FE & Yes & Yes & Yes \\
\hline Time period & 1971-2017 & $1971-2017$ & 1971-2006 \\
\hline
\end{tabular}


Table B12: Clientelism and government quality

\begin{tabular}{|c|c|c|c|}
\hline & (1) & (2) & (3) \\
\hline \multirow[t]{2}{*}{ Clientelism index $\mathrm{x}_{\mathrm{t}-1}$} & $-0.051^{* * *}$ & $-0.046^{* * *}$ & $-0.081 * * *$ \\
\hline & $(-3.678)$ & $(-3.259)$ & $(-3.757)$ \\
\hline \multirow[t]{2}{*}{ Ln population } & $0.081^{* * *}$ & $0.081 * * *$ & $0.162^{* * *}$ \\
\hline & $(9.459)$ & $(8.912)$ & $(6.706)$ \\
\hline \multirow[t]{2}{*}{ Ln GDP per capitat-1 } & $0.061^{* * *}$ & $0.062^{* * *}$ & $0.081 * * *$ \\
\hline & $(12.786)$ & $(13.234)$ & (9.731) \\
\hline \multirow[t]{2}{*}{ Electoral democracyt-1 } & & -0.040 & -0.118 \\
\hline & & $(-0.619)$ & $(-1.306)$ \\
\hline \multirow[t]{2}{*}{ Electoral democracy ${ }^{2}$} & & 0.038 & -0.020 \\
\hline & & $(0.758)$ & $(-0.243)$ \\
\hline \multirow[t]{2}{*}{ Stock of democracy } & & 0.053 & 0.130 \\
\hline & & $(1.016)$ & $(1.574)$ \\
\hline Openness & & & $\begin{array}{c}-0.001 * * * \\
(-4.697)\end{array}$ \\
\hline Education & & & $\begin{array}{c}0.015^{* *} \\
(2.281)\end{array}$ \\
\hline Life expectancy & & & $\begin{array}{c}0.004^{* * *} \\
(3.599)\end{array}$ \\
\hline Rural inequality & & & $\begin{array}{c}0.001 * * * \\
(4.861)\end{array}$ \\
\hline Civil war & & & $\begin{array}{c}-0.049 * * * \\
(-5.960)\end{array}$ \\
\hline \multirow[t]{2}{*}{ Constant } & $-0.774 * * *$ & $-0.849 * * *$ & $-2.589 * * *$ \\
\hline & $(-6.447)$ & $(-6.849)$ & $(-7.919)$ \\
\hline Observations & 4,204 & 4,194 & 2,330 \\
\hline R-squared & 0.887 & 0.890 & 0.903 \\
\hline Number of country_id & 132 & 132 & 110 \\
\hline Country FE & Yes & Yes & Yes \\
\hline Year FE & Yes & Yes & Yes \\
\hline Time period & 1985-2017 & 1985-2017 & 1985-2006 \\
\hline
\end{tabular}

Note: OLS with panel corrected standard errors. $t$-values reported in parentheses. ${ }^{*} p<0.1,{ }^{* *} p<0.05,{ }^{* * *} p$ $<0.01$.

Source: authors' elaboration based on the V-Dem data set (Coppedge et al. 2019b) and ICRG data (Dahlberg et al. 2019). 